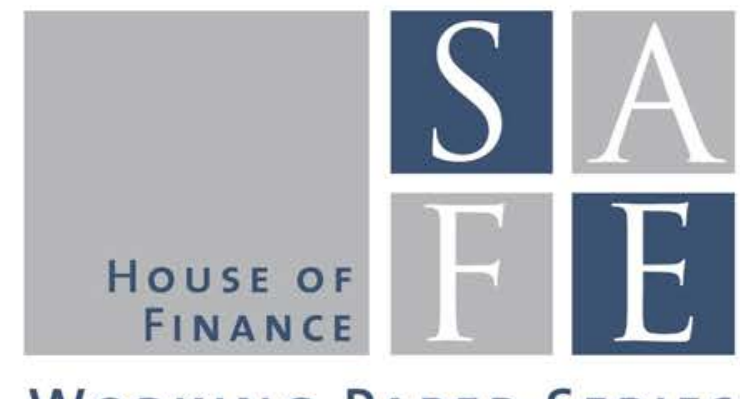

WORKING PAPER SERIES

Claudia Lambert - Felix Noth - Ulrich Schüwer

\title{
How do banks react to catastrophic events? Evidence from Hurricane Katrina
}

SAFE Working Paper No. 94

SAFE I Sustainable Architecture for Finance in Europe A cooperation of the Center for Financial Studies and Goethe University Frankfurt 


\section{Non-Technical Summary}

An important question is how banks navigate through economic crises because bank financing is crucial for economic recovery and development. From a policy perspective it would be desirable that banks continue to provide financing to borrowers, but that they also maintain their stability in an unfavorable market environment that is adversely affecting their asset quality. Previous research shows that banks reduce lending in the wake of a crisis, but little is known how banks' business decisions affect bank stability during such times, and how this is related to their lending.

This paper explores how banks react to catastrophic events, using Hurricane Katrina and two contemporary hurricanes in 2005 as a natural experiment which exposed banks' borrowers to enormous losses and thereby diminished banks' asset quality. The natural experiment allows us to provide evidence on a causal effect of a crisis on banks' business decisions, which is otherwise difficult to identify because of simultaneity and feedback effects. Our main interest is to explore banks' adjustments of risk-based capital ratios because they are a key determinant of bank stability and a cornerstone of banking regulation. Further, we are interested in bank lending to non-financial firms.

We find that independent banks (not part of a bank holding company) in the disaster areas increase their risk-based capital ratios after the hurricane, while banks that are part of a bank holding company do not. Independent banks thereby strengthen their buffer against future income shocks and mitigate bankruptcy risks. Banks that belong to a bank holding company instead seem to rely on internal capital markets and financial support within their holding structure. Further, the effect on independent banks mainly comes from the subgroup of highcapitalized banks. These banks increase their holdings in government securities and reduce loans to non-financial firms. Hence, banks that become more stable achieve this at the cost of reduced lending.

The results of the paper contribute to a better understanding on how banks navigate through crises and, given the renewed attention and importance of capital requirements for financial stability, are relevant for ongoing reforms of the banking sector. 


\title{
How do banks react to catastrophic events? Evidence from Hurricane Katrina*
}

\author{
Claudia Lambert ${ }^{\dagger}$ Felix Noth ${ }^{\ddagger}$ and Ulrich Schüwer ${ }^{\S}$
}

March 2015

\begin{abstract}
This paper explores how banks adjust their risk-based capital ratios and asset allocations following an exogenous shock to their asset quality caused by Hurricane Katrina in 2005. We find that independent banks based in the disaster areas increase their risk-based capital ratios after the hurricane, while those part of a bank holding company do not. The effect on independent banks mainly comes from the subgroup of high-capitalized banks. These banks increase their holdings in government securities and reduce loans to non-financial firms. Hence, banks that become more stable achieve this at the cost of reduced lending.
\end{abstract}

Keywords: catastrophic events, bank regulation, capital ratios, natural experiment

JEL Classification: G21, G28

\footnotetext{
*We thank Marcel Blum, Franziska Bremus, Martin Brown, Don Chance, Horst Entorf, Igor Goncharov, Florian Heider, Jan P. Krahnen, Gregory Nini, Jörg Rocholl, Joao Santos, Alexander Schäfer, Reinhard H. Schmidt, Isabel Schnabel, Adi Sunderam, Marcel Tyrell, Greg Udell, Laurent Weill, participants at the 2012 AEA annual meeting in Chicago, the 2012 CEPR Winter Conference on Financial Intermediation in Lenzerheide, the 2012 Financial Intermediation Research Society conference in Minneapolis, the 2012 European Finance Association annual meeting in Copenhagen, the 2012 DGF annual meeting in Hannover, the 2012 GEABA symposium in Graz, the 2012 Verein für Socialpolitik annual meeting in Göttingen, the 2012 French Finance Association (AFFI) annual meeting in Strasbourg as well as seminar participants at the Bank of England, Banque de France, Bank of Hungary, Bundesbank, German Institute for Economic Research (DIW Berlin), Sveriges Riksbank and UZH Zurich in 2013 for valuable comments and suggestions. Ulrich Schüwer gratefully acknowledges financial support from the Research Center SAFE, funded by the State of Hessen research initiative LOEWE.

${ }^{\dagger}$ DIW Berlin, German Institute for Economic Research, Mohrenstr. 58, 10117 Berlin, Germany. Email: clambert@diw.de.

${ }^{\ddagger}$ IWH, Halle Institute for Economic Research, Kleine Märkerstr. 8, 06108 Halle (Saale), and Otto-vonGuericke University, Department of Economics, Universitätsplatz 2, 39114 Magdeburg, Germany. Email: felix.noth@iwh-halle.de.

${ }^{\S}$ Johannes Gutenberg University Mainz, Department of Economics, Jakob Welder-Weg 4, 55128 Mainz, Germany, and Research Center SAFE at Goethe University Frankfurt, House of Finance, Theodor-W.AdornoPlatz 3, 60323 Frankfurt am Main, Germany. Email: ulrich.schuewer@uni-mainz.de.
} 


\section{Introduction}

An important question is how banks navigate through economic crises because bank financing is crucial for economic recovery and development. From a policy perspective it would be desirable that banks continue to provide financing to borrowers, but that they also maintain their stability in an unfavorable market environment that is adversely affecting their asset quality. Previous research shows that banks reduce lending in the wake of a crisis (e.g., Gan, 2007; Garmaise and Moskowitz, 2009; Ivashina and Scharfstein, 2010; Puri et al., 2011; De Haas and Van Horen, 2013), ${ }^{1}$ but little is known how banks' business decisions affect bank stability during such times, and how this is related to their lending.

This paper explores how banks adjust their risk-based capital ratios and their asset allocations in response to a crisis. We focus our analysis on risk-based capital ratios because they are a key determinant of bank stability and a cornerstone of banking regulation. When assessing banks' asset allocations, we are in particular interested in bank lending to non-financial firms. The challenge for such an analysis is twofold: First, to identify the direction of the relationship between a crisis and the banks' business decisions. ${ }^{2}$ Second, to control for parallel economic developments, which may also affect banks' financial figures but not result from active changes in banks' financing or investment decisions.

In order to identify causality between a bank's asset quality and its capital ratio, we use Hurricane Katrina and two contemporary hurricanes, which struck the U.S. Gulf Coast in the third and fourth quarters of 2005, as a natural experiment. Hurricane Katrina ranks among the costliest natural disasters in United States history with estimated property damages ranging from $\$ 100$ to over $\$ 200$ billion (National Hurricane Center, 2005; Congleton, 2006). The hurricane exposed banks in the U.S. Gulf Coast region to unexpected losses and weakened their asset quality because a large part of the damages for borrowers was not insured. Further, it caused uncertainty for banks with respect to how individual and commercial borrowers

\footnotetext{
${ }^{1}$ The different crises explored in these studies are the land market collapse in Japan in the early 1990s (Gan, 2007), the Northridge earthquake in California in 1994 (Garmaise and Moskowitz, 2009) and the recent financial crisis (all others).

${ }^{2}$ The direction of the relationship is difficult to identify because one the one hand, a crisis affects banks' business decisions, and on the other hand, banks' business decisions may cause a crisis if many banks make similar financing or investment decisions.
} 
would cope with the damages. Asymmetric information between banks and their borrowers increased, and it was also uncertain how the overall economy in the affected regions would recover from the shock. The FDIC (2006) characterized the situation as follows:

\begin{abstract}
Hurricane Katrina had a devastating effect on the U.S. Gulf Coast region that will continue to affect the business activities of the financial institutions serving this area for the foreseeable future. Some of these institutions may face significant loan quality issues caused by business failures, interruptions of borrowers' income streams, increases in borrowers' operating costs, the loss of jobs, and uninsured or underinsured collateral damage.
\end{abstract}

Along the same lines, the major rating agencies announced close monitoring of capital adequacy and the risk-management processes of affected banks in the aftermath of Hurricane Katrina (Moody's, 2005a,b). Hurricane Katrina also led to a change in the perceived hurricane risks, as reflected in property insurance premium increases of $30 \%$ or more (USA TODAY, 2010).

Using this natural experiment, we investigate the following questions: How do banks adjust their risk-based capital ratios in response to the adverse shock on their asset quality through the 2005 hurricane season? Do different types of banks show different responses, namely independent banks and banks belonging to a bank holding company? Does it matter for the response whether banks are low-capitalized or high-capitalized before Hurricane Katrina occured? And what are the mechanisms how banks adjust their risk-based capital ratios in response to the shock, in particular as regards lending to non-financial firms?

In order to answer these questions we analyze a large sample of U.S. banks within a differencein-difference framework. The treatment group comprises affected banks while the control group comprises unaffected banks in the U.S. Gulf Coast region and neighbouring states. We include bank and time fixed effects in the regressions, and, for robustness, also a proxy for credit demand, a set of bank-specific controls and regional characteristics.

The key findings of our empirical analysis are as follows: Independent banks in the disaster areas increase their risk-based capital ratios after the hurricane relative to the control group 
(unaffected by the shock), while those that are part of a bank holding company do not. Independent banks thereby strengthen their buffer against future income shocks and mitigate bankruptcy risks. Our results hence suggest that asset quality is an important determinant of banks' risk-based capital ratios as long as a bank is not backed by a larger banking organization. When we examine low-capitalized and high-capitalized banks separately, we find that this precautionary behavior only holds for high-capitalized banks. A potential explanation is that banks with high franchise values and/or high bankruptcy costs have incentives to avoid bankruptcy, and are thus characterized by high-capital ratios (before a hurricane) and precautionary behavior (after a hurricane). Further, our analysis shows that high-capitalized banks react to the lower asset quality through the hurricane by shifting investments from commercial and industrial loans to U.S. government securities, and thereby increase their risk-based capital ratios. The analysis thus provides evidence that banks that become more stable achieve this at the cost of reduced lending.

Fig. 1 illustrates this trade-off. As shown in panel (a), independent banks affected by the event on average increase their risk-based capital ratios relative to the control group. Further, panel (b) illustrates that these banks on average decrease loans to non-financial firms (commercial \& industrial loans over assets) relative to the control group.

[Fig. 1]

Our research is closely linked to several strands of literature. First, we contribute to the literature that analyzes the relationship between asset quality (or, related, asset risk) and bank capital. Previous studies face the difficulty that asset quality and bank capital are typically determined simultaneously by banks. Using simultaneous equations, two-stage, or standard OLS estimation techniques, these studies typically find a positive relation between asset risk and capital ratios, i.e., a negative relation between asset quality and capital ratios (e.g., Shrieves and Dahl, 1992; Flannery and Rangan, 2008; Gropp and Heider, 2010). Our findings are in line with findings from these studies and add further evidence on the relation between a bank's asset quality and risk-based capital ratios, using an exogenous shock on banks' asset quality. Importantly, we also consider different bank characteristics, i.e., independent banks vs. banks that are part of a bank holding company and low-capitalized vs. high- 
capitalized banks, providing evidence of how these characteristics are related to the banks' risk-based capital ratio adjustments in the wake of a crisis. Previous empirical evidence on the role of risk-based capital ratios shows a positive relation between this measure and bank stability. E.g., Berger and Bouwman (2013) find that higher precrisis bank capital, measured as equity-to-assets or risk-based capital ratio, is associated with higher survival probability during banking crisis. Demirguc-Kunt et al. (2013) show that higher leverage and regulatory capital ratios are associated with better stock market performance during the financial crisis. Hence, our results on banks' capital ratio adjustments are also relevant for the understanding of bank stability.

Second, the results of this paper contribute to studies that evaluate the consequences of various types of crisis on bank lending. For example, using the land-price collapse in Japan in the early 1990s as exogenous shock, Gan (2007) reports that firms with greater collateral losses receive less credit and reduce investments. Garmaise and Moskowitz (2009) use the 1994 Northridge earthquake in California to show that earthquake risk impacts credit markets through a more than 20 percent decreased provision of commercial real estate loans. Chavaz (2014) finds that banks with more concentrated portfolios in markets affected by the 2005 hurricanes maintain lending in markets hit by the shock and circumvent potential capital constraints through loan sales. Cortes and Strahan (2014) show that following natural disasters, multi-market banks reallocate funds toward markets affected by the disasters (with high credit demand) and away from other markets unaffected by the disasters. As regards the recent financial crisis, the literature finds that financially sticken banks reduced lending, which also led to lower corporate investment. Ivashina and Scharfstein (2010) find that banks are less likely to cut down on lending if sufficient refinancing from deposits is available such that they do not need to rely on short-term debt. Santos (2011) shows that banks with larger losses during the subprime crisis requested higher loan spreads from their corporate borrowers relative to banks with smaller losses. Puri et al. (2011) find that the U.S. crisis led to a contraction in banks' retail lending in Germany for banks that experienced losses within their banking organizations. Further, cross-border lending decreased during the financial crisis (Giannetti and Laeven, 2012), but deeper financial integration of banks in foreign countries is associated with more stable cross-border credit (De Haas and Van Horen, 2013). Our paper presents complementary evidence that in particular high-capitalized banks that are independent (not 
part of a bank holding company) cut their loans to non-financial firms while they increase their investments in risk-free U.S. government securities.

The paper proceeds as follows. In Section 2 we provide background information on the 2005 hurricane season and how it affected the economy in the U.S. Gulf Coast region. Section 3 presents the data and identification strategy. Section 4 shows our empirical model and the estimation results, while Section 5 concludes.

\section{Background on Hurricane Katrina and the 2005 hurricane season}

The heavy winds, rain and flooding brought by Hurricane Katrina met the mainland on August 29, 2005, having swept north from the Gulf of Mexico. Only weeks later, on September 24, 2005, Hurricane Rita came ashore, amplifying the effects of Hurricane Katrina. Finally, one month later in October 2005, Hurricane Wilma made landfall in Florida. Overall the 2005 hurricane season caused massive destruction and had significant negative effects on the economy in the affected U.S. Gulf Coast region.

\subsection{Damage estimates}

Hurricane Katrina, Rita and Wilma rank among the costliest natural disasters in the history of the United States. Estimated property damages from Hurricane Katrina alone range from approximately $\$ 100$ billion (National Hurricane Center, 2005; Hazards \& Vulnerability Research Institute, 2014), $\$ 125$ billion to $\$ 150$ billion (Congressional Research Service, 2013), and up to over $\$ 200$ billion (Congleton, 2006). Among its destructive effects, Hurricane Katrina made approximately 300,000 homes uninhabitable, which caused more than 400,000 citizens to move (Congressional Research Service, 2013). While Hurricane Katrina brought significantly more destruction than Hurricane Rita or Hurricane Wilma, all three hurricanes rank among the most intense and costliest hurricanes over the last 100 years (National Hurricane Center, 2011; Hurricane Research Division, 2015). 
Estimated yearly losses from natural disasters over the period 1960 to 2012, based on data from the Hazards \& Vulnerability Research Institute (2014), are illustrated in Fig. 2. The estimate for 2005 is about $\$ 120$ billion, which includes losses from Hurricane Katrina (about $\$ 100$ billion), Hurricane Rita (about $\$ 10$ billion) and Hurricane Wilma (about $\$ 10$ billion). The figure shows that the losses from the 2005 hurricane season exceed losses of previous and subsequent periods by far. Therefore, while areas affected by Hurricane Katrina, Rita and Wilma are located in hurricane states where hurricanes are not uncommon, the extraordinary impact of the 2005 hurricane season suggests that a significant part of the occurred damages was unexpected.

[Fig. 2]

\subsection{Insurance payments and federal disaster assistance}

The effect of natural disasters on households and institutions is mitigated through insurance payments and federal disaster assistance. Such support is significant, but cannot offset the huge losses from a natural disaster. This is especially so when the magnitude of a natural disaster is huge and unexpected as in the case of the 2005 hurricane season.

According to the Insurance Information Institute (2014), about 50\% of losses from the 2005 natural disasters were insured. The American Insurance Services Group (AISG) estimates that Katrina is responsible for $\$ 41.1$ billion of insured losses in the United States (National Hurricane Center, 2005). As a consequence of these unprecedented losses, insurance prices in catastrophe-prone areas were expected to rise and insurance terms and conditions were expected to be tightened, "as insurers seek to control their aggregate hurricane exposure" (Towers Watson, 2005). Hence, in addition to the immediate losses from the 2005 hurricane season, individuals and firms in affected areas were also facing more expensive and restricted insurance contracts, which made it more difficult to protect against potential disasters in the future.

In addition to potential insurance payments, the federal government of the U.S. offers assistance and funding through a variety of agencies and programs. In order to coordinate the 
response to a disaster, the Federal Emergency Management Agency (FEMA) was created in 1979. Following the announcement of a Presidential Disaster Declaration, FEMA's disaster assistance programs provide assistance to individuals ("individual assistance"), jurisdictions ("public assistance") and funds for "hazard mitigation". ${ }^{3}$ Individual assistance is directed to individuals and families whose property has been damaged and whose losses are not covered by insurance. Public assistance supports state or local governments to rebuild a community's damaged infrastructure, which includes "debris removal, emergency protective measures and public services, repair of damaged public property, loans needed by communities for essential government functions and grants for public schools"(FEMA, 2015). Funds for hazard mitigation are used to "assist communities in implementing long-term measures to help reduce the potential risk of future damages to facilities" (U.S. Government Accountability Office, 2012). The majority of federal assistance is funded through FEMA's Disaster Relief Fund, which made obligations of roughly $\$ 40$ billion with respect to damages caused by Hurricane Katrina (U.S. Government Accountability Office, 2012).

\subsection{Implications for the economy}

Despite financial support through insurance payments and federal disaster assistance, the 2005 hurricanes were expected to have "substantial and long-term effects on the economies of southern Louisiana and Mississippi" (Congressional Research Service, 2005). The left graph of Fig. 3 depicts the number of initial jobless claims filed in Louisiana between 2000 and 2009. ${ }^{4}$ It shows a significant increase in the third and fourth quarters of 2005, mirroring the desolate situation during the 2005 hurricane season. The right graph illustrates the development of the CredAbility Consumer Distress Index in Louisiana, which is published by the St. Louis Fed and measures the financial condition of the average consumer. The index incorporates various data including employment, housing, credit scores, household budget and net worth. ${ }^{5}$ A higher measure of the index mirrors a more favorable situation of the average household.

\footnotetext{
${ }^{3}$ Other minor categorizes are "mission assignments" and "administration" (U.S. Government Accountability Office, 2012).

${ }^{4}$ The source for the number of initial jobless claims is the FRED online database of the St. Louis Fed (http://research.stlouisfed.org/fred2/).

${ }^{5}$ For details, see http://research.stlouisfed.org/fred2/release?rid=260. Note that the index was discontinued in 2013 .
} 
The index shows the dramatic consequences for the financial situation of Louisiana households right after the 2005 hurricane season: an all-time low in the fourth quarter of 2005 , even below the levels during the recent financial crisis.

[Fig. 3]

Previous research also points to the adverse effects of hurricanes on local economic conditions. For example, Strobl (2011) studies hurricanes in the U.S. over the period 1948 to 2005 and finds a 0.45 percentage point decline of economic growth rates in affected counties. Deryugina et al. (2014) show that Katrina victims' face an initital negative wage income shock one year after the disaster but also that the gap in wage income disappears two years after the storm.

Summing up, the 2005 hurricane season caused significant uninsured losses and - at least temporary - a significant deterioration of local economic conditions. Last but not least, this created uncertainty how households and the economy would recover from the disaster.

\section{$3 \quad$ Identification strategy and data}

This sections starts with a description of our identification strategy. The following subsections provide detailed information on the characteristics of our sample.

\subsection{Identification of affected and unaffected banks}

Following Hurricane Katrina and the contemporary Hurricanes Rita and Wilma in the second half of 2005, FEMA designated 135 out of 534 counties in the Gulf Coast region (Louisiana, Mississippi, Texas, Florida and Alabama) as eligible for individual and public disaster assistance. ${ }^{6}$ Using this information we classify a bank as affected by a hurricane if its headquarters is located in a county that was eligible for individual and public disaster assistance (dark-grey shaded region in Fig. 4). Next we classify a bank as unaffected if its headquarters is located in

\footnotetext{
${ }^{6}$ Source: https://www.fema.gov/disasters.
} 
a county not affected by the hurricanes and located in the U.S. Gulf Coast region or a neighboring state (light-grey shaded area in Fig. 4). Last, we exclude a bank from the sample if its headquarters is located in a county eligible for public disaster assistance but not eligible for individual disaster assistance, because this criterion is ambiguous. For example, counties in the northwest Texas region were very distant from the wind fields, but designated for public assistance. A possible reason is that they were affected indirectly through the accommodation of disaster evacuees or other minor effects. To guarantee that we are dealing with banks that were clearly affected or clearly not affected by the hurricane, we exclude banks from these counties. Consequently, we are left with a clean identification of banks located in affected counties and banks located in unaffected counties.

[Fig. 4]

\subsection{Data sources and sample description}

Our data come from several public sources. As regards the impact of the 2005 hurricanes (Katrina, Rita and Wilma) on the U.S. Gulf Coast region, we use data from FEMA, as described above. Our bank data come from the Statistics on Depository Institutions database of the Federal Deposit Insurance Corporation (FDIC). ${ }^{7}$ This data set includes quarterly balance sheet and income data of all FDIC-insured U.S. banks. We also use bank-level data on mortgage lending activities, which are available from the Federal Financial Institutions Examination Council (FFIEC) and reported by banks under the Home Mortgage Disclosure Act. ${ }^{8}$ These data provide information on home mortgage enquiries from bank customers and are used in this study to control for credit demand before and after the 2005 hurricanes. We also use quarterly unemployment data at the county level from the Bureau of Labor Statistics ${ }^{9}$ which allows us to examine the robustness of our results with regard to time-varying macroeconomic conditions.

For our main analysis we restrict our sample to banks located in the U.S. Gulf Cost region or

\footnotetext{
${ }^{7}$ Source: https://www2.fdic.gov/sdi/index.asp.

${ }^{8}$ Source: http://www.ffiec.gov/hmda/.

${ }^{9}$ Source: http://www.bls.gov/lau/.
} 
neighboring states: Alabama, Arkansas, Florida, Georgia, Louisiana, Mississippi, North Carolina, Oklahoma, South Carolina, Tennessee and Texas. ${ }^{10}$ This preliminary sample consists of 2,583 banks doing business at the end of the second quarter of 2005, i.e., the quarter before the hurricanes hit the U.S. Gulf Coast. Further, for our baseline sample, we only consider banks that do not belong to a bank holding company, what we refer to as independent banks, which results in a preliminary sample of 706 banks. ${ }^{11}$ These independent banks share features with community banks discussed by DeYoung et al. (2004) and are a viable part of the U.S. banking sector. We only consider independent banks in our baseline regressions because, at first, we want to exclude effects from internal capital markets within bank-holding groups that are due to capital allocations or implicit and explicit guarantees (see, e.g., Houston et al., 1997; Froot and Stein, 1998). We include both independent banks and banks that are part of a bank holding company in a set of extended regressions.

Earlier studies that also use FDIC data point out that some of the data are erroneous or include rather atypical institutions. Therefore, similar to Berger and Bouwman (2009), we exclude banks that (1) have no commercial real estate or commercial and industry loans outstanding; (2) have zero or negative equity capital; (3) hold assets below $\$ 25$ million, or (4) hold consumer loans exceeding $50 \%$ of gross total assets. We also leave out atypical institutions with risk-based capital ratios above $40 \%$, which represents five times the regulatory requirement of $8 \%$. This reduces the sample to 532 banks. Since we want to exclude biases from newly founded banks, we require banks' existence two years before the third quarter of 2005, which leaves us with a sample of 422 banks. Finally, as described in the previous section, we only consider banks that are located in a county that was clearly affected or clearly not affected by the 2005 hurricane season, which results in our final sample of 257 banks, of which 93 were affected and 164 are unaffected by the 2005 hurricane season.

\footnotetext{
${ }^{10}$ In a set of robustness regressions, we also use a sample of banks from both narrower and wider geographic areas (see Section 4.5 and Table 7 ).

${ }^{11}$ Technically, we require that the FDIC data field namehcr, which denotes a bank-holding company, is left blank.
} 


\subsection{Variables description and summary statistics}

Our main explanatory variable is the exogenous adverse shock on banks' asset quality caused by Hurricane Katrina, Rita and Wilma in Q3 and Q4 2005. Asset quality reflects the "quantity of existing and potential credit risk associated with the loan and investment portfolios, other real estate owned, and other assets, as well as off-balance sheet transactions" (Federal Reserve Board, 2014). The 2005 hurricanes caused significant unexpected losses and increased credit risks for banks in affected regions. We are thus able to identify a causal relation between asset quality and our dependent variables. Measures for asset quality, which are frequently used in the literature, are risk-weighted assets (e.g., Avery and Berger, 1991), the standard deviation of the return on assets or the standard deviation of (unlevered) stock price returns (e.g., Gropp and Heider, 2010; Flannery and Rangan, 2008). In our study, we circumvent using these traditional measures, which cause endogeneity concerns, because banks typically determine their asset quality and capital ratio simultaneously.

The dependent variable that we use in our baseline regressions is a bank's quarterly risk-based capital ratio. ${ }^{12}$ We thereby explore how banks adjust their risk-based capital ratios during the two year period following the 2005 hurricane season. The banks in our sample operate in a Basel I regulatory environment. Consequently, they can assign risk weights corresponding to five different categories that range from zero to 100\%. For example, U.S. government securities have a risk weight of zero, residential mortgage loans have a risk weight of $50 \%$, and commercial and industrial loans have a risk weight of $100 \%$. Banks are required to hold capital equal to at least $8 \%$ of risk-weighted assets.

Other dependent variables used in this study, which allow us to explore the mechanisms how banks adjust their capital ratios, are total capital, risk-weighted assets, U.S. government securities, real estate loans, real estate commercial loans, consumer loans and commercial and industrial loans. All these variables are standardized by total assets and winsorized at $1 \%$ from above and below.

\footnotetext{
${ }^{12}$ Risk-based capital ratios are equivalent to the sum of the bank's Tier 1 and Tier 2 capital divided by its risk-weighted assets. For some banks, the nominator also includes Tier 3 capital allocated for market risk, net of all deductions. For details, see "Schedule RC-R - Regulatory Capital" of the FDIC.
} 
Further, for some specifications, we use the regional unemployment rate from the county where a bank has its headquarters to control for time-varying differences in local economic conditions.

For a description of all variables used in this study, see Table 1.

\section{[Table 1]}

Summary statistics are provided in Table 2. All statistics refer to the average values of the two year period before the 2005 hurricane season, i.e., Q3 2003 to Q2 2005. The table reports mean values and standard deviations separately for both groups of affected and unaffected banks, as well as normalized differences, which is discussed in more detail below.

[Table 2]

\subsection{Similarity between treatment and control group}

It is important for the validity of the difference-in-difference estimation that banks in our treatment group (affected banks) and banks in our control group (unaffected banks) have similar characteristics before the event. As suggested by Imbens and Wooldridge (2009), we report summary statistics with normalized differences to compare the similarity between both groups as regards important bank characteristics. ${ }^{13}$ As a rule of thumb, groups are regarded as sufficiently equal and adequate for linear regression methods if normalized differences are largely in the range of \pm 0.25 .

The summary statistics reported in Table 2 confirm that the groups of affected and unaffected banks are relatively similar before the event. In particular, banks in both groups hold, on average, similar levels of risk-based capital ratios of around $17 \%$ during the two years prior to the 2005 hurricane season. Normalized differences of 0.03 are clearly in the range of \pm 0.25 . Note that the level of $17 \%$ substantially exceeds the regulatory minimum of $8 \%$. This

\footnotetext{
${ }^{13}$ Normalized differences are calculated as "the difference in averages by treatment status, scaled by the square root of the sum of the variances" (Imbens and Wooldridge, 2009, p. 24).
} 
observation is in line with Flannery and Rangan (2008), who also report relatively high ratios for U.S. banks. We also find for all 14 reported bank-level variables, with the exception of consumer loans, that normalized differences are in the range of \pm 0.25 . At the regional level, we find that the regional unemployment rate is similar in counties where banks affected or unaffected by the 2005 hurricanes have their headquarters. The regional share of commercial banks is also similar for both groups of banks.

Overall, we find that bank-level and regional characteristics of both groups of banks are similar before the event and, hence, that the treatment and control groups are well suited for our analysis.

\section{Empirical analysis}

In this section we explore how a deterioration in banks' asset quality through the 2005 hurricane season affects banks' capital ratios and asset allocation in the aftermath of the hurricanes. Anecdotal evidence on the deterioration in banks' asset quality is provided by the FDIC and rating agencies, as noted in the introduction of this paper (see, e.g., the quote from the FDIC on page 3). For empirical evidence on the adverse short-term effects of the hurricanes on bank profitability and bank stability, refer to Appendix C.

The analysis begins in Subsection 4.1 with regressions on how independent banks (not part oa a bank holding company) adjust their risk-based capital ratios following the 2005 hurricane season. Subsection 4.2 then analyzes whether and how such adjustments differ for banks that are part of a bank holding company. A key aspect for this analysis is that these banks may use internal capital markets within their bank holding companies. Subsection 4.3 assesses whether banks' pre-Katrina risk-based capital ratios matter for the adjustments, because low-capitalized and high-capitalized banks may behave differently. Subsection 4.4 explores the mechanisms how affected banks adjust their risk-based capital ratios, i.e., through adjustments on the liability side and/or through adjustments on the asset side. Results from this subsection include evidence on consequences for the provision of bank loans to non-financial firms. Last, in Subsection 4.5, we present further robustness of our results. 


\subsection{Do affected banks adjust their risk-based capital ratios?}

In this section we explore whether independent banks' risk-based capital ratios change after these banks experience an adverse shock on their asset quality through the 2005 hurricane season.

Baseline estimation. For the empirical analysis we need to consider potential parallel macroeconomic and industry-wide factors that affect all banks independent of the shock. Another concern is that unobservable bank characteristics might influence the analysis. To account for both aspects, we use a difference-in-difference estimation technique with time and bank fixed effects. Formally, we estimate the following equation with a fixed effects OLS model for a sample period of two years around the 2005 hurricane season (Q3 and Q4 2005):

$$
\operatorname{CAP}_{i t}=\nu_{i}+\beta_{1} \text { Event }_{t}+\beta_{2}\left(\text { Event }_{t} \times \text { Affected }_{i}\right)+\tau_{\gamma}+\epsilon_{i t}
$$

The dependent variable $C A P_{i t}$ is the risk-based capital ratio of bank $i$ at time $t$. The variable Event $_{t}$ is a time dummy with a value of zero for the eight quarters before the hurricanes ( $t \leq \mathrm{Q} 22005$ ) and a value of one for eight quarters after the hurricanes ( $t \geq \mathrm{Q} 12006$ ). The variable Affected $_{i}$ is a dummy variable of bank $i$ that is one if the bank is located in a county classified by FEMA as eligible for "public and private disaster assistance" and thus belongs to the treatment group, and zero otherwise (for the control group). Hence, the interaction term Event $_{t} \times$ Affected $_{i}$ is one if both the variable Event $_{t}$ and the variable Affected $_{i}$ amount to one, and zero otherwise. The corresponding coefficient $\beta_{2}$ is the main interest. It captures how affected banks adjust their risk-based capital ratios after the event relative to the control group. The terms $\nu_{i}, \tau_{\gamma}$ and $\epsilon_{i t}$ represent bank fixed effects, yearly time fixed effects and the idiosyncratic error term, respectively. Standard errors are clustered at the bank level.

For robustness, we reestimate our baseline estimation with three alternative specifications. First, we estimate Equation (1) without bank fixed effects. The variable Affected ${ }_{i}$, which otherwise interferes with bank fixed effects, then enters the equation.

Second, we consider potential concerns that a shortfall in credit demand in affected regions 
may drive our results. Technically, such a shortfall may lead to lower risk-weighted assets and consequently higher risk-based capital ratios of affected banks. However, a shortfall in credit demand is unlikely because of reconstruction activities. As stated by the Federal Reserve Bank of Atlanta (2005), credit demand was rather expected to increase in affected regions in the aftermath of the 2005 hurricanes. Nevertheless, we add a control variable for banks' credit demand in a robustness specification. The general difficulty for such a control variable is that it needs to disentangle credit demand from credit supply. Therefore, a bank's reported loan volume is not suitable. However, we can use data reported by banks under the Home Mortgage Disclosure Act to build a proxy for credit demand. In particular, banks are required under this act to report the volume of all mortgage applications on a yearly basis. We use this data to calculate credit demand $_{i j}$ per bank $i$ and year $j$ as the log of the dollar volume of each bank's mortgage applications (accepted and denied mortgages). We then include the variable credit demand $_{i j}$ in Equation (1). Note that this reduces our sample from 257 to 178 banks, because the data is not available for all banks.

Third, we estimate Equation (1) with further control variables which are common in the banking literature. In particular, we add the return on assets (RoA), the ratio of nonperforming loans to assets and bank size (log of the total number of employees). ${ }^{14}$ Note that these control variables only matter for the estimation to the degree that they are time variant because they are otherwise already included in the bank fixed effects. Further, to capture differences in local economic developments, we use quarterly unemployment rates at the county level as an additional time-varying control variable.

Baseline results. We present our baseline results in Table 3. Column (1) shows the difference-in-difference estimation with bank fixed effects and without further covariates, as reflected in Equation (1). With regard to our main variable of interest, the interaction term Event $_{t} \times$ Affected $_{i}$, we observe a positive and significant coefficient that shows that affected banks increase their capital ratios after the hurricane relative to the control group. This effect is also economically significant. The risk-based capital ratio of affected banks increases on average by 1.06 percentage points, as shown by the point estimate of the interaction term.

\footnotetext{
${ }^{14}$ Results remain qualitatively the same if we use total assets instead of total number of employees for bank size or RoE instead of $R o A$.
} 
Column (2) shows results for our baseline estimation of Equation (1) without bank fixed effects. The results remain robust and confirm the relatively higher risk-based capital ratios of banks after the event. The average effect of the hurricanes on banks' risk-based capital ratios, which is reflected in the coefficient of the interaction term $\beta_{2}$, is 1.5 percentage points and in the same range as before.

Next, we again include bank fixed effects as well as a proxy for credit demand in the regression. We find that results remain intact. The effect on banks' capital ratios, as reflected in a $\beta_{2}$ of 1.34 percentage points, is again in the range of estimation results in Column (1).

Finally, we add bank characteristics that are regarded as relevant for banks' capital ratios as well as the unemployment rate in a bank's home county to control for macroeconomic developments. We find that banks' risk-based capital ratios decreases in bank size, but are not significantly affected by the other new covariates. Importantly, the coefficient of the interaction term which is our main interest, remains in the same range as before.

[Table 3]

Summing up, this set of results strongly advocates that independent banks react when confronted with an adverse shock on their asset quality. They do this by increasing their risk-based capital ratio relative to banks that do not experience this shock. The results suggest that banks thereby strengthen their cushion against insolvency.

This finding adds to Flannery and Rangan (2008) who suggest that a change in the banking environment rather than supervisory pressure leads to higher capital ratios for U.S. banks during the 1990s. Similarly, Gropp and Heider (2010) argue that banks rely on their "own judgement" to define the appropriate amount of total risk-based capital and that regulatory requirements are of second-order importance. 


\subsection{The role of internal capital markets for capital ratio adjustments}

In this section we explore whether banks that are part of a bank holding company, which we refer to as $B H C$ banks, adapt their capital ratios in a similar way than independent banks, which have been the sole focus of the analysis so far. Contrary to independent banks, bank holding companies have the opportunity to establish internal capital markets to allocate capital across their various subsidiaries (Houston et al., 1997). BHC banks are thus more flexible in case of financial problems and may rely on this instead of building higher capital ratios by themselves.

Estimation. For the following analysis, we extend the sample from 257 independent banks by $992 \mathrm{BHC}$ banks. This results in a total sample of 1,249 banks, of which 305 were affected by the 2005 hurricanes and 944 were unaffected. Formally, we extend Equation (1) to differentiate between independent banks and $\mathrm{BHC}$ banks and estimate the following equation:

$$
\begin{aligned}
\mathrm{CAP}_{i t} & =\nu_{i}+\beta_{1} \text { Event }_{t}+\beta_{2}\left(\text { Event }_{t} \times \text { Affected }_{i}\right)+\beta_{3}\left(\text { Event }_{t} \times \mathrm{BHC}_{i}\right) \\
& +\beta_{4}\left(\text { Event }_{t} \times \text { Affected }_{i} \times \mathrm{BHC}_{i}\right)+\tau_{\gamma}+\epsilon_{i t} .
\end{aligned}
$$

The variable $\mathrm{BHC}_{i}$ has a value of 0 for independent banks and a value of 1 for $\mathrm{BHC}$ banks. In comparison to Equation (1), the interaction terms Event $t_{t} \times B H C_{i}$ and Event $t_{t} \times$ Affected $_{i}$ $\times B H C_{i}$ are now included in the model. As such we estimate a difference-in-difference-indifference model that analyzes whether the effect on affected independent banks (relative to before the hurricanes and relative to unaffected independent banks) is different from the effect on affected BHC banks (relative to before the hurricanes and relative to unaffected

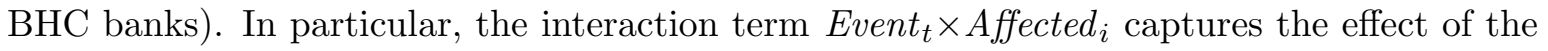
2005 hurricanes on independent banks, and the the coefficient of the triple interaction term Event $_{t} \times$ Affected $_{i} \times B H C_{i}$ captures whether and how the effect is different for BHC banks. Note that the terms $B H C_{i}$ and Affected $_{i} \times B H C_{i}$ are captured by the bank fixed effects and are therefore not included in the equation.

As before, we run the regressions using total risk-based capital as the dependent variable for four specifications: (1) with bank fixed effects as reflected in the equation above; (2) without 
bank fixed effects; (3) with bank fixed effects controlling for credit demand; and (4) with bank fixed effects controlling for credit demand and some additional covariates that are common in the literature.

Results. As shown in Column (1) of Table 4, we find that the coefficient of the triple interaction term, which shows the differential effect for BHC banks, is significant and negative. The magnitude of this coefficient of -0.0094 is also very close to the magnitude of the coefficient of the double interaction term of +0.0106 . Hence, the total effect is +0.0012 for BHC banks $(\mathrm{BHC}=1)$ while it is +0.0106 for independent banks $(\mathrm{BHC}=0)$. The bottom rows of Table 4 contrast these effects for both groups of banks and also show the respective standard errors. Accordingly, the effect is significant for independent banks on the $5 \%$ level and insignificant for BHC banks. Results remain robust when we estimate the equation without bank fixed effects (Column (2)), control for credit demand (Column (3)) or include additional bank covariates (Column (4)).

\section{[Table 4]}

In summary, we observe that affected independent banks adjust their risk-based capital ratios after the event while affected banks that belong to a bank holding company do not. This indicates that BHC banks rely on potential financial support from their bank holding company, which they can access through internal capital markets and, therefore, do not build up precautionary capital reserves internally.

\subsection{The role of bank capitalization for capital ratio adjustments}

Bank capitalization is a key determinant of bank risk in the supervisory assessment. Banks with low capital ratios are considered as less stable than banks with high capital ratios. ${ }^{15}$ In this section we are interested in whether banks with lower or higher capital ratios before

\footnotetext{
${ }^{15}$ Different capital ratios of banks are typically related to different business models, which can be more or less risky, and reflect aspects such as investment opportunities, bankruptcy costs, franchise value, value of deposit guarantees and bank governance.
} 
Hurricane Katrina struck the U.S. Gulf Coast, i.e., banks that are considered less stable or more stable by the banking supervisor, differ in their capital ratio adjustments after the hurricanes.

We calculate a bank's pre-Hurricane Katrina (risk-based) capital ratio, denoted as $R B C R_{i}$, in two steps: First, we calculate for each bank the mean value of its risk-based capital ratio over the eight quarters before Hurricane Katrina (Q3 2003 to Q2 2005). Second, we demean these values across all banks in the sample. Hence, $R B C R_{i}$ has a mean value of zero. These pre-Hurricane Katrina capital ratios range from $-8.2 \%$ to $20.5 \%$ (or, before demeaning, from $9.2 \%$ to $37.8 \%$ with a mean of $17.4 \%){ }^{16}$

Estimation. We extend Equation (1) by interacting the variables Event and Event $\times$ Affected with banks' pre-Hurricane Katrina capital ratios. Formally, we estimate the following equation for the sample of independent banks with a fixed effects OLS model:

$$
\begin{aligned}
\mathrm{CAP}_{i t} & =\nu_{i}+\beta_{1} \text { Event }_{t}+\beta_{2}\left(\text { Event }_{t} \times \text { Affected }_{i}\right)+\beta_{3}\left(\text { Event }_{t} \times \mathrm{RBCR}_{i}\right) \\
& +\beta_{4}\left(\text { Event }_{t} \times \text { Affected }_{i} \times \mathrm{RBCR}_{i}\right)+\tau_{\gamma}+\epsilon_{i t} .
\end{aligned}
$$

The first coefficient of interest is $\beta_{2}$ and refers to Event $\times$ Affected, which now shows how a bank with a mean pre-Hurricane Katrina capital ratio $\left(R B C R_{i}=0\right)$ adjusts its capital ratio after the hurricanes relative to the control group. The second coefficient of interest is $\beta_{4}$ and refers to Event $\times$ Affected $\times R B C R$, which shows whether (and how) the previous effect differs across different levels of $R B C R$. As before, we run the regressions using risk-based capital ratios as the dependent variable for four specifications: (1) with bank fixed effects, (2) without bank fixed effects, (3) with bank fixed effects controlling for credit demand; and (4) with bank fixed effects controlling for credit demand and some additional covariates.

Results. As shown in Column (1) of Table 5, the coefficient of the interaction term Event $\times$ Affected is positive and significant with a value of 0.0106 . This means that affected

\footnotetext{
${ }^{16}$ More than $95 \%$ of banks held an average pre-Katrina risk-based capital ratio (before demeaning) above $10 \%$, which is well above the required $8 \%$ and considered as "well capitalized" by the FDIC. Further requirements to be classified as "well capitalized" by the FDIC are a Tier 1 risk-based capital ratio equal to or greater than $6 \%$ and a Tier 1 leverage capital ratio equal to or greater than $5 \%$.
} 
banks with a pre-Hurricane Katrina capital ratio of zero (equal to the mean level across all banks) significantly increase their risk-based capital ratio after the event relative to the control group (unaffected banks with the same pre-Hurricane Katrina capital ratio of zero). This result is in line with the previous results shown in Table 3 . When we consider whether this effect is significantly different across different levels of $R B C R$, we observe a positive but insignificant coefficient of the triple interaction term Event $\times$ Affected $\times R B C R$. Hence, the effect Event $\times$ Affected is not significantly different across different levels of $R B C R$. Nevertheless, results appear more nuanced when we evaluate this effect at different percentiles of the distribution of $R B C R_{i}$. As shown in the rows at the bottom of Table 5, we observe that banks with pre-Hurricane Katrina capital ratios at the 75th percentile of the distribution (RBCR of $2.7 \%$ or, before demeaning, $20.1 \%$ ) significantly increase their risk-based capital ratios by 1.43 percentage points after the hurricanes, relative to the control group. On the contrary, estimations for banks with pre-Hurricane Katrina capital ratios at the 25th percentile of the distribution (RBCR of $-4.7 \%$ or, before demeaning, $12.7 \%$ ) show insignificant results. This suggests that the key message of the previous regressions that banks in disaster areas increase their risk-based capital ratios after the hurricanes mainly comes from banks that are relatively high-capitalized. This finding also holds for the OLS estimations in Column (2), the fixed-effects estimation that controls for credit demand in Column (3), and the fixed-effects estimation with additional control variables in Col (4) of Table 5.

[Table 5]

The analysis yields an interesting result about how different banks react to the adverse shock on their asset quality through the hurricanes. Banks that appear ex ante relatively conservative in their business model - or at least hold relatively large capital buffers - also react conservatively to the shock and further increase their buffers against future losses. The effect becomes smaller and insignificant for banks that appear more risky in their business model - or at least hold relatively smaller capital buffers. From the perspective of the supervisor, these banks are presumably those that should increase their buffers against future losses, but as our evidence shows, these banks are not capable or not willing to do so. 


\subsection{Mechanisms of capital ratio adjustments}

This section examines the mechanisms how banks adjust their risk-based capital ratios. Generally, banks can do so by adjusting their total capital, which is the numerator of the ratio and reflects their liability side, or by adjusting their risk-weighted assets, which is the denominator of the ratio and reflects their asset side.

Baseline estimation. Formally, we estimate the same model as before in Equation (3), which considers banks' pre-Hurricane Katrina capital ratios (RBCR), but replace the dependent variable:

$$
\begin{aligned}
\mathrm{Y}_{i t} & =\nu_{i}+\beta_{1} \text { Event }_{t}+\beta_{2}\left(\text { Event }_{t} \times \text { Affected }_{i}\right)+\beta_{3}\left(\text { Event }_{t} \times \mathrm{RBCR}_{i}\right) \\
& +\beta_{4}\left(\text { Event }_{t} \times \text { Affected }_{i} \times \mathrm{RBCR}_{i}\right)+\tau_{\gamma}+\epsilon_{i t},
\end{aligned}
$$

where $\mathrm{Y}_{i t}$ stands for total capital, risk-weighted assets, government securities, commercial and industrial loans, real estate loans, real estate commercial loans and consumer loans. All variables are standardized by total assets and winsorized at $1 \%$ from above and below. For unreported robustness regressions, we also include a proxy for credit demand as well as further control variables (RoA, NPL, bank size, regional unemployment rate), equivalent to the extended regressions in the previous sections.

Results for total capital. The first column of Table 6 shows regression results of Equation (4) using total capital over assets as dependent variable. We find a positive and significant coefficient of 0.0039 for the interaction term Event $\times$ Affected. Hence, affected banks with a mean pre-Hurricane Katrina capital ratio $(R B C R=0)$ significantly increase their total capital over assets after the event relative to the control group (unaffected banks with the same pre-Hurricane Katrina capital ratio of zero). The coefficient of the triple interaction term Event $\times$ Affected $\times R B C R$ is positive but not significant, which means that the effect Event $\times$ Affected is not significantly different across different levels of $R B C R$. Nevertheless, when we evaluate the effect for banks with level of $R B C R$ at the 25 th and 75 th percentile of the distribution, we find no significant effects for banks with lower levels of $R B C R$, but 
significant effects for banks with higher levels of $R B C R$. Coefficients and standard errors are shown in the bottom rows of the table. Hence, the effect that affected banks increase their total capital over assets following the hurricanes in Q3 and Q4 2005 is driven by banks that were relatively highly capitalized before Hurricane Katrina struck the region, and not by banks that were relatively lowly capitalized. When we include a proxy for credit demand and several control variables (RoA, NPL, bank size, regional unemployment rate) in Eq. 4, we find in unreported robustness regressions that coefficients of interest point to the same directions, but the effects become insignificant both for banks with level of RBCR at the 25th and 75 th percentile of the distribution.

Results for risk-weighted assets. Next, we use risk-weighted assets over assets (RWA/assets) as dependent variable in the regressions of Equation (4). Results in Column (2) of Table 6 show an insignificant coefficient of -0.0116 for the effect Event $\times$ Affected, which captures how banks with a pre-Hurricane Katrina capital ratio of zero adjust their risk-weighted assets over assets relative to the control group. The coefficient of the triple interaction term is also insignificant. Nevertheless, the evaluation of the effect at different levels of $R B C R$ shows that affected banks with a value of $R B C R$ at the 75 th percentile significantly decrease their risk-weighted assets over assets relative to the control group (see bottom rows of the table). Again, this indicates that the increased risk-based capital ratios of affected banks following the hurricanes (relative to the control group) are driven by affected banks with relatively high pre-Hurricane Katrina capital ratios. As before, the effects become insignificant both for banks with level of RBCR at the 25th and 75th percentile of the distribution when we include a proxy for credit demand and several control variables in the regressions of Eq. 4 .

In addition, we explore several asset categories that determine a bank's risk-weighted assets. In particular, U.S. government securities have a risk-weight of zero, real estate loans have a risk-weight between $50 \%$ and $100 \%$ (e.g., typically $50 \%$ for loans to individuals or families and $100 \%$ for commercial real estate loans), consumer loans as well as commercial and industrial loans have a risk-weight of $100 \%$.

Results for U.S. government securities. Regression results of Equation (4) with U.S. 
government securities over assets (GOV/assets) as dependent variable are shown in Column (3) of Table 6 . We find that affected banks with a level of $R B C R$ of zero significantly increase their holdings of U.S. government securities over assets relative to the control group, as reflected in the significantly positive coefficient of the interaction term Event $\times$ Affected. We also find a significantly positive coefficient of the interaction term Event $\times$ Affected $\times R B C R$, which means that the effect is significantly stronger for banks with higher levels of $R B C R$. When we compare banks at the 25 th percentile with banks at the 75 th percentile of the distribution of $R B C R$, the effect is 2.59 percentage points higher for the latter (0.0273-0.0014). Compared with banks' average holdings of government securities around 17 percent, this difference is economically highly relevant. Results remain qualitatively unchanged when we include a proxy for credit demand and several control variables in the regressions of Eq. 4 .

Results for loan types including commercial and industrial loans. We now take a closer look at different loan categories. Therefore, the following loan categories are assessed in Table 6 and serve as the dependent variable: real estate loans over assets (RE loans/assets), commercial real estate loans over assets, (RECO loans/assets), consumer loans over assets (CON loans/assets), and commercial and industrial loans over assets (C\&I loans/assets).

We find significant effects of interest for the last loan category (C\&I loans), and not for the other loan categories. The significantly negative coefficient of -0.0096 for the interaction term Event $\times$ Affected means that affected banks with a value of $R B C R$ at the mean $(R B C R=0)$ reduce their C\&I loans relative to the control group. This negative effect becomes stronger for banks with higher levels of $R B C R$, as reflected in the negative coefficient of the triple interaction term. However, differences across different levels of $R B C R$ are not significant. Similar to previous results, the effect is insignificant for banks with relatively low pre-Hurricane Katrina capital ratios, but significant for bank with relatively high pre-Hurricane Katrina capital ratios (see the coefficients and standard errors for the 25 th percentile and 75 the percentile of $R B C R$ at the bottom of the table). All results for loan types remain qualitatively unchanged when we include a proxy for credit demand and several control variables in the regressions of Eq. 4. 
[Table 6]

Overall, the evidence on the mechanisms of capital ratio adjustments of banks affected by the 2005 hurricanes provides two insights: First, affected banks increase their holdings in U.S. government securities and reduce their holdings in C\&I loans relative to the control group. This finding adds to evidence from previous studies on a decline in bank lending in the wake of a crisis (e.g., Garmaise and Moskowitz, 2009). Second, the evidence suggests that the effect mainly comes from banks with relatively high pre-Hurricane Katrina capital ratios. For all the mechanisms described above, we find significant results for banks with pre-Hurricane Katrina capital ratios at the mean level across all banks $(R B C R=0)$ or at the 75 th percentile of the distribution. In contrast, effects are always insignificant for banks with pre-Hurricane Katrina capital ratios at the 25 th percentile.

\subsection{Further robustness}

Alternative regional samples. This subsection examines whether a smaller or larger sample of the states that we consider for the composition of the control and the treatment groups might change our main results. Recall that our main results are based on a sample with 93 affected banks and 164 unaffected banks in Alabama, Florida, Louisiana, Mississippi, Texas, Georgia, Tennessee, Arkansas and Oklahoma. To check robustness, we make the following changes: First, we restrict the sample to banks that only operate in Alabama and Florida. The reason is that only these states comprise both counties affected and counties unaffected by the hurricane. Second, we restrict the sample to counties in the core states affected by the hurricane (Louisiana, Mississippi, Texas, Florida, and Alabama) and thus exclude banks in neighboring states (Georgia, Tennessee, Arkansas, and Oklahoma) from the control group relative to our baseline sample. Third, we extend the sample to banks in neighboring U.S. Southeastern states, that is, South Carolina and North Carolina, and thus add banks from these states to the control group.

We rerun our main regression and provide results for our baseline sample and the three alternative regional samples in Table 7. Across all groups we find significant results for the 
treatment effect from Hurricane Katrina on the risk-based capital ratio of affected banks. We also find that the effect is economically stronger for the Alabama and Florida region (Column (1)). Here, affected banks increase their risk-based capital ratio by 2.28 percentage points relative to their unaffected peers after the event. Considering the largest sample in the last column, we find very similar results to our baseline regression in Table 3. Overall, Table 7 shows that our results do not hinge on the choice of a specific regional sample or control group.

\section{[Table 7]}

Parallel-trend assumption. To alleviate potential biases we have to guarantee that the parallel-trend assumption prior to the treatment is satisfied. In other words, the risk-based capital ratios should follow a similar trend for the treatment and control groups. Analogous to previous studies, in Fig. 1 we graphically inspect the trend of mean total risk-based capital for both groups and confirm the parallel-trend assumption. Further, as already discussed in Subsection 3.4 and shown in Table 2, the groups of affected and unaffected banks are largely similar with respect to common bank characteristics.

Cross-section estimation. In order to show that the results are robust against problems with difference-in-difference techniques in the presence of serial correlation, Bertrand et al. (2004) suggest ignoring the time structure of the data. Therefore, we average the data before and after the hurricane and rerun the estimation for this collapsed sample.

Table 8 presents results for the collapsed baseline sample over the four different time periods. We find the treatment effect for all different periods intact and in the range of 1.15 to 1.48 percentage points.

[Table 8]

Time-placebo estimation. The possibility that the results are driven by time trends unrelated to Hurricane Katrina needs to be ruled out. Therefore, we run a "placebo estimation" 
where the treatment shifts from the time period when Hurricane Katrina, Rita and Wilma actually occurred (Q3 and Q4 of 2005) to a time period three years earlier (Q3 and Q4 of 2002). We then rerun the estimation for observations two years before and after this "2002 pseudo hurricane" event. As before, we run the regressions using total risk-based capital as the dependent variable for four specifications: (1) with bank fixed effects; (2) without bank fixed effects; (3) with bank fixed effects controlling for credit demand; and (4) with bank fixed effects controlling for demand and some additional covariates that are common in the literature. Table 9 shows the results for this analysis, which can be directly compared to our baseline results in Table 3. We do not find an effect for the 2002 pseudo hurricane in any of the specifications. This finding supports our assumption that our results are not driven by factors unrelated to Hurricane Katrina.

[Table 9]

\section{Conclusion}

In this paper we explore how banks react to catastrophic events, using Hurricane Katrina and two contemporary hurricanes in 2005 as a natural experiment that exposed banks' borrowers to enormous losses and thereby diminished banks' asset quality. In particular, we assess how banks adjust their risk-based capital ratios following this shock, and how this is related to their asset allocations. The natural experiment allows us to provide evidence on a causal effect of a crisis on banks' business decisions, which is otherwise difficult to identify because of mutual influences and feedback effects.

We find that banks in the disaster areas that are independent increase their risk-based capital ratios after the hurricane, while those that are part of a bank holding company do not. Affected banks that are independent thereby strengthen their buffer against future income shocks and mitigate bankruptcy risks. This shows that asset quality is an important determinant of banks' risk-based capital ratios for this group of banks. Banks that belong to a bank holding company, however, do not significantly increase their risk-based capital ratios. The likely reason is that these banks have access to internal capital markets and financial support 
within their holding structure. Further, we find that the effect on independent banks is driven by risk-based capital ratio adjustment of banks with already relatively high risk-based capital ratios before Hurricane Katrina struck the U.S. Gulf Coast. Relatively low-capitalized banks do not show any significant increases of their risk-based capital ratios following the 2005 hurricanes. This again demonstrates that the behavior of banks cannot be generalized for all banks but depends on bank characteristics. Apparently, affected banks with a relatively cautious business model (reflected in relatively high risk-based capital ratios before Hurricane Katrina) also behave cautiously after the disaster by increasing their risk-based capital ratios. Banks with relatively low risk-based capital ratios, which may be more risky and cause more worries for banking supervisors, are not capable or not willing to build higher capital buffers against potential future losses. Finally, our evidence shows that increases in banks' risk-based capital ratios are associated with reductions in bank lending. In particular, the banks that increase their risk-based capital ratios increase their holdings in risk-free U.S. government securities and reduce lending to non-financial firms. The analysis thus provides evidence that banks that become more stable achieve this at the cost of reduced lending. Given the renewed attention for financial stability and capital requirements of banks, these results are valuable for ongoing reforms of the banking sector.

\section{References}

Avery, R. B., Berger, A. B., 1991. Risk-based capital and deposit insurance reform. Journal of Banking \& Finance 15, 847-874.

Berger, A., Bouwman, C., 2009. Bank liquidity creation. Review of Financial Studies 22, $3779-3837$.

Berger, A. N., Bouwman, C. H., 2013. How does capital affect bank performance during financial crises? Journal of Financial Economics 109 (1), 146 - 176.

Bertrand, M., Duflo, E., Mullainathan, S., 2004. How much should we trust differences-indifferences estimates? Quarterly Journal of Economics 119, 249-275.

Chavaz, M., 2014. Riders of the storm: Economic shock \& bank lending in a natural experiment. Working Paper. 
Congleton, R., 2006. The story of Katrina: New Orleans and the political economy of catastrophe. Public Choice 127, 5-30.

Congressional Research Service, 2005. The macroeconomic effects of Hurricane Katrina. Report for Congress, prepared by B. Cashell and M. Labonte.

Congressional Research Service, 2013. Federal disaster assistance after Hurricanes Katrina, Rita, Wilma, Gustav, and Ike. Report for Congress, prepared by B.R. Lindsay, and J.C. Nagel.

Cortes, K. R., Strahan, P. E., 2014. Tracing out capital flows: How financially integrated banks respond to natural disasters. FRB of Cleveland Working Paper.

De Haas, R., Van Horen, N., 2013. Running for the exit? International bank lending during a financial crisis. Review of Financial Studies 26, 244-285.

Demirguc-Kunt, A., Detragiache, E., Merrouche, O., 2013. Bank capital: lessons from the financial crisis. Journal of Money, Credit and Banking 45, 1147-1164.

Deryugina, T., Kawano, L., Levitt, S., 2014. The economic impact of Hurricane Katrina on its victims: Evidence from individual tax returns. NBER Working Paper No. 20713.

DeYoung, R., Hunter, W. C., Udell, G. F., 2004. The past, present, and probable future for community banks. Journal of Financial Services Research 25, 85-133.

FDIC, 2006. Hurricane Katrina examiner guidance. Interagency supervisory guidance for institutions affected by Hurricane Katrina.

URL http://www.fdic.gov/news/news/financial/2006/fil06012.html (Download 25 October 2014)

Federal Reserve Bank of Atlanta, 2005. Annual Report 2005: Resilience.

Federal Reserve Board, 2014. Supervisory policy and guidance topics: Asset quality.

URL http://www.federalreserve.gov/bankinforeg/topics/asset_quality.htm (Download 01 December 2014) 
FEMA, 2015. The disaster process and disaster aid programs.

URL https://www.fema.gov/disaster-process-disaster-aid-programs (Download 20 January 2015)

Flannery, M. J., Rangan, K. P., 2008. What caused the bank capital build-up of the 1990s? Review of Finance 12, 391-429.

Froot, K. A., Stein, J. C., 1998. Risk management: capital budgeting and capital structure policy for financial institutions: An integrated approach. Journal of Financial Economics $47,55-82$.

Gan, J., 2007. Collateral, debt capacity, and corporate investment: Evidence from a natural experiment. Journal of Financial Economics 85, 709-734.

Garmaise, M., Moskowitz, T., 2009. Catastrophic risk and credit markets. Journal of Finance $64,657-707$.

Giannetti, M., Laeven, L., 2012. The flight home effect: Evidence from the syndicated loan market during financial crises. Journal of Financial Economics 104, 23-43.

Gropp, R., Heider, F., 2010. The determinants of bank capital structure. Review of Finance $14,587-622$.

Gunther, J. W., Moore, R. R., 2003. Loss underreporting and the auditing role of bank exams. Journal of Financial Intermediation 12 (2), 153-177.

Hazards \& Vulnerability Research Institute, 2014. Spatial Hazard Events and Losses Database for the United States (SHELDUS).

URL http://hvri.geog.sc.edu/SHELDUS/ (Download 01 July 2014)

Houston, J., James, D., Marcus, D., 1997. Capital market frictions and the role of internal capital markets in banking. Journal of Financial Economics 46, 135-164.

Hurricane Research Division, 2015. National Oceanic \& Atmospheric Administration revisits historic hurricanes.

URL http://www.aoml.noaa.gov/hrd/hurdat/ (Download 09 January 2015) 
Imbens, G. W., Wooldridge, J. M., 2009. Recent developments in the econometrics of program evaluation. Journal of Economic Literature 47, 5-86.

Insurance Information Institute, 2014. Catastrophes: U.S.

URL http://www.iii.org/fact-statistic/catastrophes-us (Download 01 December 2014)

Ivashina, V., Scharfstein, D., 2010. Bank lending during the financial crisis of 2008. Journal of Financial Economics 97, 319-338.

Moody's, 2005a. Moody's comments on Hurricane Katrina's impact on regional bank ratings. Global Credit Research, 08 Sep 2005.

Moody's, 2005b. Moody's outlines possible Katrina effect on local banks. Market Watch, 08 Sep 2005.

National Hurricane Center, 2005. Tropical cyclone report. Report, prepared by Knaab, R. D. and Rhome, J. R. and Brown, D.P.

URL http://www.nhc.noaa.gov/pdf/TCR-AL122005_Katrina.pdf (Download 05 January 2015)

National Hurricane Center, 2011. The deadliest, costliest, and most intense United States tropical cyclones from 1851 to 2010. Working Paper; prepared by Blake, E. S. and Landsea, C. W. and Gibney, E. J.

Puri, M., Rocholl, J., Steffen, S., 2011. Global retail lending in the aftermath of the us financial crisis: Distinguishing between supply and demand effects. Journal of Financial Economics 100, 556-578.

Santos, J. A. C., 2011. Bank corporate loan pricing following the subprime crisis. Review of Financial Studies 24, 1916-1943.

Shrieves, R. E., Dahl, D., 1992. The relationship between risk and capital in commercial banks. Journal of Banking \& Finance 16, 439-457.

Strobl, E., 2011. The economic growth impact of hurricanes: Evidence from US coastal counties. Review of Economics and Statistics 93, 575-589. 
Towers Watson, 2005. Hurricane Katrina: Analysis of the impact on the insurance industry.

URL http://www.towerswatson.com/en/Insights/IC-Types/Ad-hoc-Point-of-View/Perspectives/

U.S. Government Accountability Office, 2012. Federal Disaster Assistance, improved criteria needed to assess a jurisdiction's capability to respond and recover on its own.

URL http://www.gao.gov/assets/650/648162.pdf (Download 09 January 2015)

USA TODAY, 2010. 5 years after Katrina, homeowners insurance costs more (August 26).

URL http://www.usatoday.com/money/industries/insurance/(Download 18 April 2011) 


\section{A Figures}

Figure 1: Impact of the 2005 hurricanes on banks' risk-based capital ratios and loans

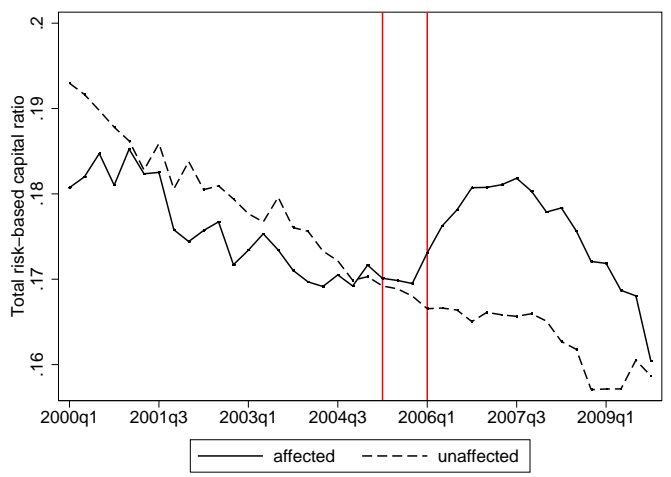

(a) Risk-based capital ratios

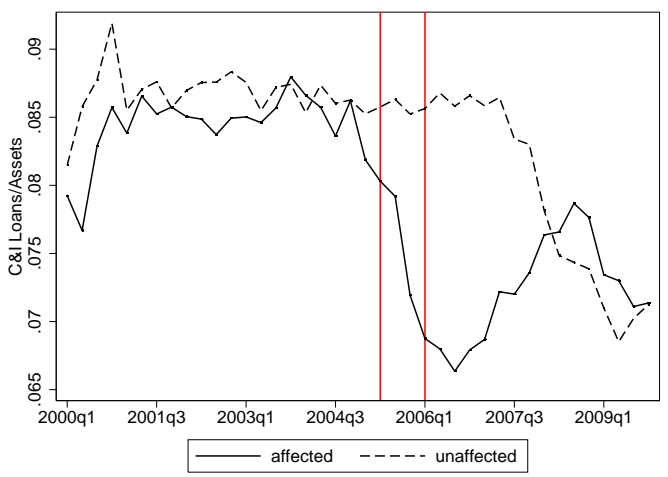

(b) Commercial and industrial loans

The graphs show the development of banks' risk-based capital ratios and commercial and industrial loans over assets (C\&I loans/Assets) from the first quarter of 2000 through the fourth quarter of 2009. The mean values for independent banks located in areas affected by Hurricane Katrina or the contemporary Hurricanes Rita and Wilma are represented by a solid line. The mean values for independent banks located in the U.S. Gulf Coast region or neighbouring states but not affected by the hurricanes are represented by a dotted line. The solid vertical lines indicate the quarters around the disaster period of the third and fourth quarters of 2005, when Hurricanes Katrina, Rita and Wilma hit the U.S. Gulf Coast region. 
Figure 2: Annual disaster losses since 1960

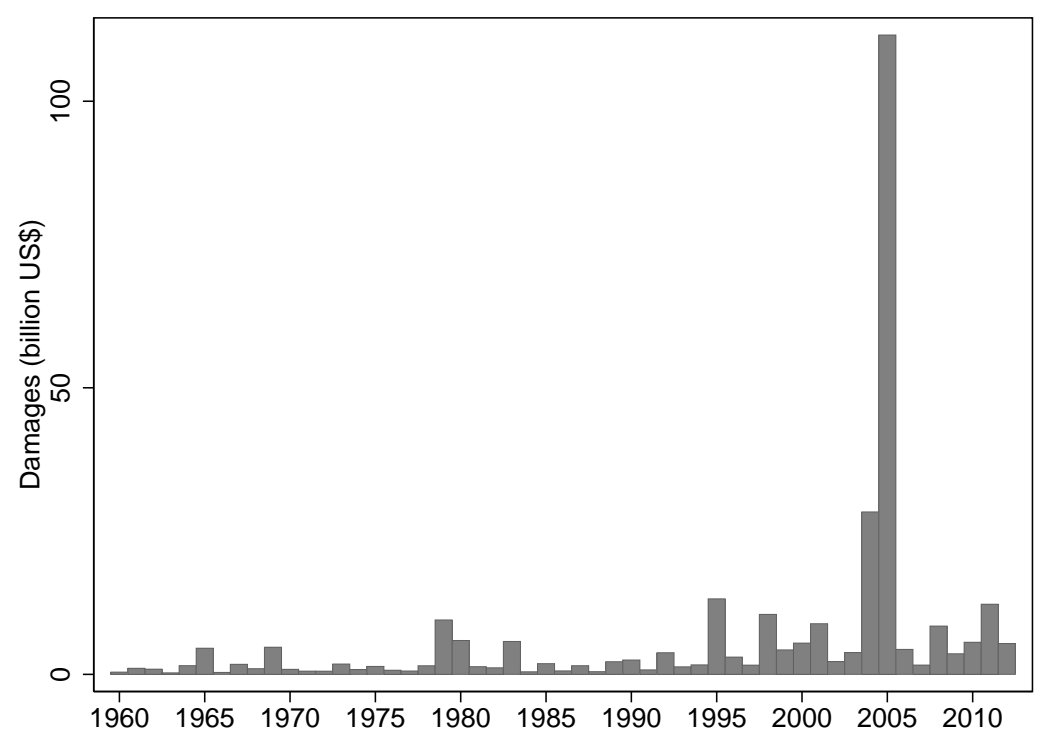

The figure shows the total sum of yearly disasters losses for the states in our baseline sample: Alabama, Louisiana, Florida, Mississippi, Georgia, Tennessee, Oklahoma and Arkansas. The numbers are expressed in \$billion and adjusted to 2011 dollar values. The data source is the Hazards \& Vulnerability Research Institute (Sheldus database).

Figure 3: Impact of Hurricane Katrina on the Louisiana economy

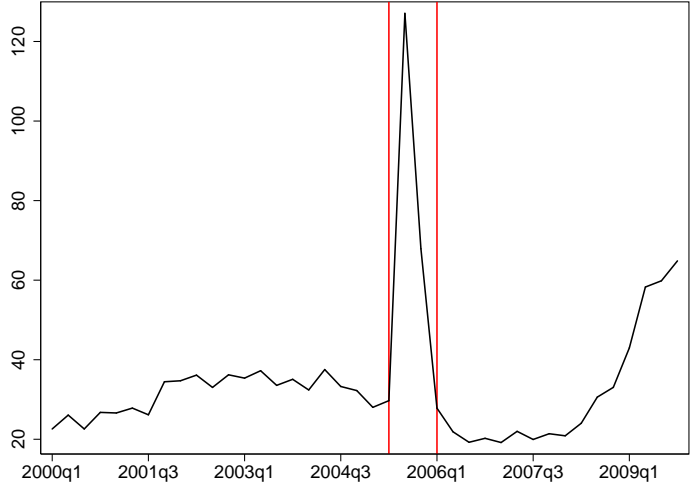

(a) Initial jobless claims

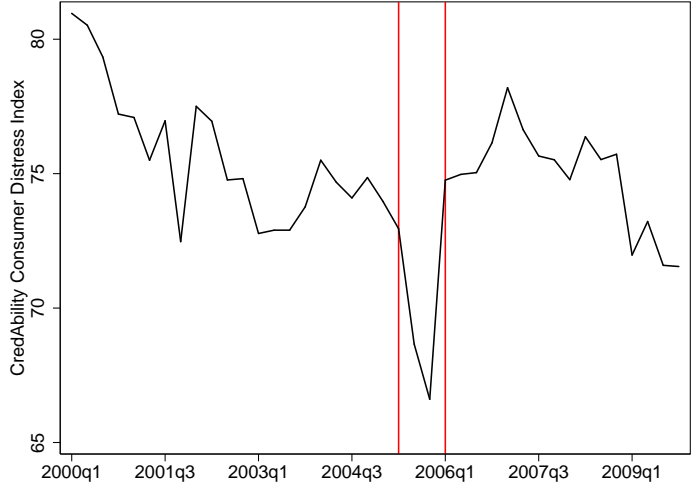

(b) CredAbility Consumer Distress Index

The left graph shows initial jobless claims (in thousand) and the right graph shows the CredAbility Consumer Distress Index for Louisiana, where a higher score shows a more favorable situation and a score under 70 indicates financial distress. Both graphs reflect quarterly values from the first quarter of 2000 through the fourth quarter of 2009. The solid vertical lines indicate the quarters around the disaster period of the third and fourth quarters of 2005, when Hurricanes Katrina, Rita and Wilma hit the U.S. Gulf Coast region. The data source for both graphs is the FRED database of the St. Louis Fed. 
Figure 4: 2005 hurricane disaster areas

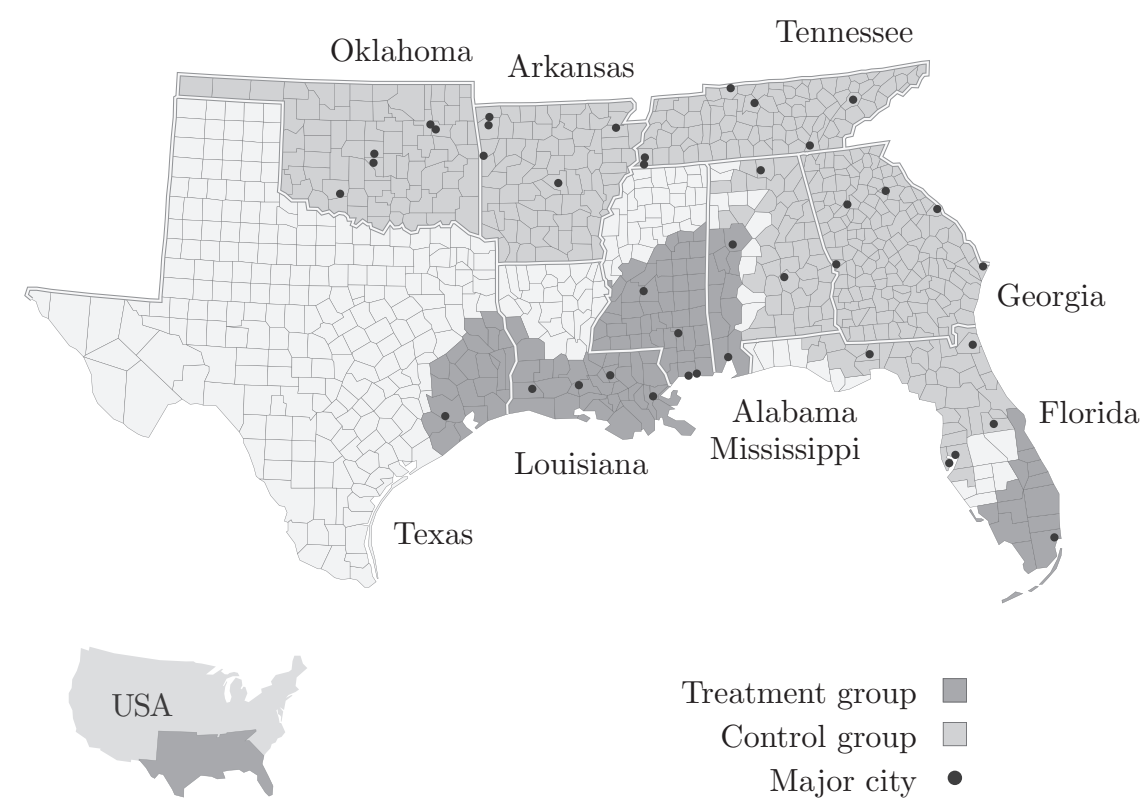

This figure shows counties in the U.S. Gulf Coast region and neighboring states that were affected by the 2005 hurricane season (Katrina, Rita and Wilma). The dark-grey shaded area comprises counties that were eligible for individual and public disaster assistance (banks with headquarters in these counties represent our treatment group). The light-grey shaded area comprises counties that did not receive disaster assistance (banks with headquarters in these counties represent our control group). The white shaded area includes counties that were eligible only for public disaster assistance (banks with headquarters in these counties are excluded from the sample). 
B Tables 
Table 1: Variable description

Notes: The source for all variables as well as their descriptions is the FDIC, if not stated otherwise. For more details, refer to http://www2.fdic.gov/SDI/main.asp.

\begin{tabular}{|c|c|c|}
\hline Variable name & FDIC code & Description \\
\hline Assets & asset & $\begin{array}{l}\text { Total assets. The sum of all assets owned by the institution } \\
\text { including cash, loans, securities, bank premises and other assets. }\end{array}$ \\
\hline Bank size & $\log ($ numemp$)$ & $\begin{array}{l}\text { Bank size. The natural logarithm of the number of full-time } \\
\text { employees on the payroll of the bank and its subsidiaries. }\end{array}$ \\
\hline $\mathrm{BHC}$ & namehcr & $\begin{array}{l}\text { Bank Holding Company bank. Dummy variable that we as- } \\
\text { sign a value of zero if "namehcr" is blank and a value of one oth- } \\
\text { erwise. }\end{array}$ \\
\hline C\&I loans & lnci & $\begin{array}{l}\text { Commercial and industrial loans. Excludes all loans secured } \\
\text { by real estate, loans to individuals, loans to depository institutions } \\
\text { and foreign governments, loans to states and political subdivisions } \\
\text { and lease financing receivables. }\end{array}$ \\
\hline CON loans & lncon & $\begin{array}{l}\text { Consumer loans. Loans to individuals for household, family, } \\
\text { and other personal expenditures including outstanding credit-card } \\
\text { balances and other secured and unsecured consumer loans. }\end{array}$ \\
\hline CredAbility & & $\begin{array}{l}\text { CredAbility Consumer Distress Index. This index measures } \\
\text { financial distress of households on a } 100 \text { point scale. A score under } \\
70 \text { indicates financial distress. Source: FRED database of the St. } \\
\text { Louis Fed. }\end{array}$ \\
\hline Credit demand & & $\begin{array}{l}\text { Credit demand. } \\
\text { loans as reported under the }\end{array}$ \\
\hline GOV & scus & $\begin{array}{l}\text { Government securities. Total U.S. Treasury securities plus } \\
\text { U.S. Government agency and corporation obligations. }\end{array}$ \\
\hline Initial jobless claims & & $\begin{array}{l}\text { Initial jobless claims. Measures the number of jobless claims } \\
\text { filed by individuals seeking to receive state jobless benefits. Source: } \\
\text { FRED database of the St. Louis Fed. }\end{array}$ \\
\hline LLA & lnatres & $\begin{array}{l}\text { Loan loss allowance. The amount a bank must maintain that } \\
\text { is adequate to absorb estimated credit losses associated with its } \\
\text { loan and lease portfolio. }\end{array}$ \\
\hline NPL & p9asset & $\begin{array}{l}\text { Non-performing loans. Total assets past due } 90 \text { or more days } \\
\text { and still accruing interest. }\end{array}$ \\
\hline RBCR & & $\begin{array}{l}\text { Pre-Hurricane Katrina (risk-based) capital ratio. Mean } \\
\text { risk-based capital ratio (rbcrwaj) over the eight quarters before } \\
\text { Hurricane Katrina, demeaned across all banks. Source: Own cal- } \\
\text { culations based on FDIC data. 's rbcrwaj. }\end{array}$ \\
\hline RE loans & lnre & $\begin{array}{l}\text { Real-estate loans. Loans secured primarily by real estate, } \\
\text { whether originated by the bank or purchased. }\end{array}$ \\
\hline RECO loans & lnrenres & $\begin{array}{l}\text { Commercial real-estate loans. Nonresidential loans primarily } \\
\text { secured by real estate. }\end{array}$ \\
\hline Regional UR & & $\begin{array}{l}\text { Regional unemployment rate. County-level information on } \\
\text { unemployment rates. Source: Bureau of Labor Economics. }\end{array}$ \\
\hline Risk-based capital ratio & rbcrwaj & $\begin{array}{l}\text { Risk-based capital ratio. Tier } 1 \text { capital and Tier } 2 \text { capital } \\
\text { divided by the bank's risk-weighted assets. For some banks, the } \\
\text { nominator also includes Tier } 3 \text { capital allocated for market risk, } \\
\text { net of all deductions. For details, see "Schedule RC-R - Regulatory } \\
\text { Capital" of the FDIC. }\end{array}$ \\
\hline RoA & roaptx & $\begin{array}{l}\text { Return over assets. Net income after taxes and extraordinary } \\
\text { items (annualized) to average total assets. }\end{array}$ \\
\hline RWA & rwaj & $\begin{array}{l}\text { Risk-weighted assets. Assets adjusted for risk-based capital } \\
\text { definitions that comprise on-balance-sheet as well as off-balance- } \\
\text { sheet items multiplied by risk weights that range from } 0 \text { to } 100 \% \\
\text { (under Basel I). }\end{array}$ \\
\hline Total capital & rbct $1 j+$ rbct 2 & Total capital. This is the sum of Tier 1 capital and Tier 2 capital. \\
\hline Total loans & $\operatorname{lnlsgr}$ & $\begin{array}{l}\text { Total loans. Total loans and lease financing receivables, net of } \\
\text { unearned income. }\end{array}$ \\
\hline Z-score & & $\begin{array}{l}\text { Z-score. We calculate the z-score for each bank and quarter as the } \\
\text { natural logarithm of the sum of a bank's return on assets (roaptx) } \\
\text { and its core capital ratio (eqv), standardized by the standard de- } \\
\text { viation ( } 12 \text { quarter rolling) of the bank's return on assets. Source: } \\
\text { Own calculations based on FDIC data. }\end{array}$ \\
\hline
\end{tabular}


Table 2: Descriptive statistics

This table reports descriptive statistics for all variables used in later analyses for the period two years before the hurricane event in 2005. We provide mean values and standard deviations for independent banks (i.e., they do not belong to a $\mathrm{BHC}$ ) that reside in counties that were affected by the hurricane (affected) and banks operating in counties unaffected by the event (unaffected). The sample consists of 93 affected and 164 unaffected independent banks. The sample includes all banks in Alabama, Louisiana, Mississippi, Florida, Texas, Georgia, Tennessee, Arkansas and Oklahoma. The last two columns show the normalized differences (Norm. Diff.) according to Imbens and Wooldridge (2009) and compare differences between independent banks that were affected versus banks that were not affected ((1) vs (2)). As a rule of thumb, groups are regarded as sufficiently equal and adequate for linear regression methods if normalized differences are largely in the range of \pm 0.25 . A detailed description of all variables is given in Table 1.

\begin{tabular}{|c|c|c|c|c|c|}
\hline & \multicolumn{2}{|c|}{ (1) affected } & \multicolumn{2}{|c|}{ (2) unaffected } & \multirow{2}{*}{$\begin{array}{l}\text { Norm. Diff. } \\
\text { (1) vs (2) }\end{array}$} \\
\hline & Mean & $\mathrm{SD}$ & Mean & $\mathrm{SD}$ & \\
\hline \multicolumn{6}{|l|}{ Bank-level variables } \\
\hline Assets & 244.8142 & 836.5487 & 396.2019 & 1091.4568 & -0.1101 \\
\hline Bank size & 3.8412 & 0.9819 & 3.5775 & 0.8791 & 0.2001 \\
\hline C\&I loans/Assets & 0.0866 & 0.0642 & 0.0860 & 0.0775 & 0.0061 \\
\hline Commercial real estate loans/Assets & 0.1486 & 0.1123 & 0.1687 & 0.1281 & -0.1179 \\
\hline Consumer loans/Assets & 0.0732 & 0.0603 & 0.0488 & 0.0486 & 0.3146 \\
\hline Government securities/Assets & 0.1703 & 0.1385 & 0.1760 & 0.1409 & -0.0289 \\
\hline Loan loss allowance/Assets & 0.0008 & 0.0053 & 0.0009 & 0.0042 & -0.0083 \\
\hline Non-performing assets/Assets & 0.0016 & 0.0030 & 0.0013 & 0.0029 & 0.0643 \\
\hline Real estate loans/Assets & 0.4861 & 0.1860 & 0.4976 & 0.2042 & -0.0414 \\
\hline Risk-based capital ratio & 0.1733 & 0.0630 & 0.1706 & 0.0577 & 0.0312 \\
\hline Risk-weighted assets/Assets & 0.6830 & 0.1208 & 0.6436 & 0.1216 & 0.2295 \\
\hline RoA & 0.0112 & 0.0111 & 0.0122 & 0.0131 & -0.0582 \\
\hline Total capital/Assets & 0.1136 & 0.0306 & 0.1057 & 0.0274 & 0.1935 \\
\hline Total loans/Assets & 0.6706 & 0.1543 & 0.6444 & 0.1708 & 0.1139 \\
\hline \multicolumn{6}{|l|}{ Regional variables } \\
\hline Regional unemployment rate & 0.0563 & 0.0124 & 0.0542 & 0.0146 & 0.1068 \\
\hline \multicolumn{6}{|l|}{ Sample size } \\
\hline Number of banks & 93 & & 164 & & \\
\hline Number of observations & 1404 & & 2603 & & \\
\hline
\end{tabular}


Table 3: Baseline results

This table shows results for regressions of Equation (1) in which banks' total risk-based capital ratio is the dependent variable. The sample includes all independent banks (not part of a bank holding company) in Alabama, Louisiana, Mississippi, Florida, Texas, Georgia, Tennessee, Arkansas and Oklahoma over the period of \pm 2 years around the 2005 hurricane season (Q3 2003 to Q4 2007).

Event is a dummy variable that is zero for the pre-hurricane period and one after the hurricane season. Affected is a dummy variable that separates banks located in counties that were affected by the hurricanes (Affected=1) and banks located in counties that were unaffected (Affected=0). Event $\times$ Affected is an interaction term for the variables Event and Affected. Credit demand is the log of the volume of loan applications as reported under the Home Mortgage Disclosure Act. RoA is banks' return over assets. NPL represents non-performing loans over assets. Bank size is the natural logarithm of banks' number of employees. Regional unemployment rate represents the quarterly unemployment rate for the county where a bank's headquarters is based. A detailed description of all variables is given in Table 1.

Bank fixed effects (Bank FE) and year dummies (Time FE) are included in the regressions as stated in the table below. We show clustered standard errors on bank level in parentheses. The adjusted R-squared is the within R-squared for regressions with bank fixed effects. The $* * *, * *$ and $*$ stand for significant coefficients at the $1 \%, 5 \%$, and $10 \%$ levels, respectively.

\begin{tabular}{|c|c|c|c|c|}
\hline & \multicolumn{4}{|c|}{ risk-based capital ratio } \\
\hline Event & $\begin{array}{r}-0.0138^{* * *} \\
(0.0034)\end{array}$ & $\begin{array}{r}-0.0113^{* * *} \\
(0.0030)\end{array}$ & $\begin{array}{r}-0.0060^{* *} \\
(0.0025)\end{array}$ & $\begin{array}{r}-0.0031 \\
(0.0025)\end{array}$ \\
\hline Event $\times$ Affected & $\begin{array}{r}0.0106^{* *} \\
(0.0045)\end{array}$ & $\begin{array}{r}0.0154^{* * *} \\
(0.0052)\end{array}$ & $\begin{array}{r}0.0134^{* *} \\
(0.0054)\end{array}$ & $\begin{array}{r}0.0134^{* *} \\
(0.0052)\end{array}$ \\
\hline Affected & & $\begin{array}{r}-0.0027 \\
(0.0075)\end{array}$ & & \\
\hline Credit demand & & & $\begin{array}{r}0.0002 \\
(0.0029)\end{array}$ & $\begin{array}{r}0.0005 \\
(0.0028)\end{array}$ \\
\hline RoA & & & & $\begin{array}{r}-0.0021 \\
(0.0027)\end{array}$ \\
\hline NPL & & & & $\begin{array}{r}0.0605 \\
(0.2675)\end{array}$ \\
\hline Bank size & & & & $\begin{array}{r}-0.0278^{* * *} \\
(0.0087)\end{array}$ \\
\hline Regional unemployment rate & & & & $\begin{array}{r}0.1326 \\
(0.1304)\end{array}$ \\
\hline Constant & $\begin{array}{r}0.1774^{* * *} \\
(0.0016)\end{array}$ & $\begin{array}{r}0.1768^{* * *} \\
(0.0049)\end{array}$ & $\begin{array}{r}0.1623^{* * *} \\
(0.0214)\end{array}$ & $\begin{array}{r}0.2648^{* * *} \\
(0.0466)\end{array}$ \\
\hline Bank FE & Yes & No & Yes & Yes \\
\hline Time FE & Yes & Yes & Yes & Yes \\
\hline N. of Banks & 257 & 257 & 178 & 178 \\
\hline N. of Obs. & 3779 & 3779 & 2589 & 2589 \\
\hline Adj. R2 & 0.0325 & 0.0042 & 0.0336 & 0.0695 \\
\hline
\end{tabular}


Table 4: The role of internal capital markets

This table shows results for regressions of Equation (2) in which banks' total risk-based capital ratio is the dependent variable and the terms Event, Affected and Event $\times$ Affected are interacted with a dummy variable that indicates independent banks $(B H C=0)$ or banks that belong to a bank holding company $(B H C=1)$. The sample includes all banks in Alabama, Louisiana, Mississippi, Florida, Texas, Georgia, Tennessee, Arkansas and Oklahoma over the period of \pm 2 years around the 2005 hurricane season (Q3 2003 to Q4 2007).

At the bottom, we present estimates of the difference-in-difference effect of Event $\times$ Affected for independent banks $(\mathrm{BHC}=0)$ and for banks that belong to a bank holding company $(\mathrm{BHC}=1)$.

Event is a dummy variable that is zero for the pre-hurricane period and one after the hurricane season. Affected is a dummy variable that separates banks located in counties that were affected by the hurricanes (Affected=1) and banks located in counties that were unaffected (Affected=0). Event $\times$ Affected is an interaction term for the variables Event and Affected. Credit demand is the log of the volume of loan applications as reported under the Home Mortgage Disclosure Act. RoA is banks' return over assets. NPL represents non-performing loans over assets. Bank size is the natural logarithm of banks' number of employees. Regional unemployment rate represents the quarterly unemployment rate for the county where a bank's headquarters is based. A detailed description of all variables is given in Table 1.

Bank fixed effects (Bank FE) and year dummies (Time FE) are included in the regressions as stated in the table below. We show clustered standard errors on bank level in parentheses. The adjusted R-squared is the within R-squared for regressions with bank fixed effects. The $* * *, * *$ and $*$ stand for significant coefficients at the $1 \%, 5 \%$, and $10 \%$ levels, respectively.

\begin{tabular}{|c|c|c|c|c|}
\hline \multirow[b]{2}{*}{ Event } & \multicolumn{4}{|c|}{ risk-based capital ratio } \\
\hline & $\begin{array}{r}-0.0064^{* * *} \\
(0.0025)\end{array}$ & $\begin{array}{r}-0.0056^{* *} \\
(0.0028)\end{array}$ & $\begin{array}{r}-0.0063^{* *} \\
(0.0028)\end{array}$ & $\begin{array}{r}-0.0081^{* * *} \\
(0.0029)\end{array}$ \\
\hline Event $\times$ Affected & $\begin{array}{r}0.0106^{* *} \\
(0.0045)\end{array}$ & $\begin{array}{r}0.0154^{* * *} \\
(0.0052)\end{array}$ & $\begin{array}{r}0.0134^{* *} \\
(0.0054)\end{array}$ & $\begin{array}{r}0.0134^{* *} \\
(0.0052)\end{array}$ \\
\hline Event $\times$ BHC & $\begin{array}{r}0.0044 \\
(0.0027)\end{array}$ & $\begin{array}{r}0.0030 \\
(0.0029)\end{array}$ & $\begin{array}{r}0.0033 \\
(0.0030)\end{array}$ & $\begin{array}{r}0.0032 \\
(0.0029)\end{array}$ \\
\hline Event $\times$ Affected $\times$ BHC & $\begin{array}{r}-0.0094^{*} \\
(0.0049)\end{array}$ & $\begin{array}{r}-0.0140^{* *} \\
(0.0055)\end{array}$ & $\begin{array}{r}-0.0101^{*} \\
(0.0058)\end{array}$ & $\begin{array}{r}-0.0107^{*} \\
(0.0057)\end{array}$ \\
\hline Affected & & $\begin{array}{r}-0.0027 \\
(0.0075)\end{array}$ & & \\
\hline $\mathrm{BHC}$ & & $\begin{array}{r}-0.0200^{* * *} * \\
(0.0051)\end{array}$ & & \\
\hline Affected $\times$ BHC & & $\begin{array}{r}0.0072 \\
(0.0084)\end{array}$ & & \\
\hline Credit demand & & & $\begin{array}{r}-0.0002 \\
(0.0011)\end{array}$ & $\begin{array}{r}-0.0002 \\
(0.0011)\end{array}$ \\
\hline RoA & & & & $\begin{array}{r}-0.0008 \\
(0.0013)\end{array}$ \\
\hline NPL & & & & $\begin{array}{r}-0.0132 \\
(0.1238)\end{array}$ \\
\hline Bank size & & & & $\begin{array}{r}-0.0160^{* * *} \\
(0.0043)\end{array}$ \\
\hline Regional unemployment rate & & & & $\begin{array}{r}0.0675 \\
(0.0887)\end{array}$ \\
\hline Constant & $\begin{array}{r}0.1565^{* * * *} \\
(0.0004)\end{array}$ & $\begin{array}{r}0.1715^{* * *} \\
(0.0048) \\
\end{array}$ & $\begin{array}{r}0.1489 * * * \\
(0.0083)\end{array}$ & $\begin{array}{r}0.2205^{* * *} \\
(0.0212) \\
\end{array}$ \\
\hline Bank FE & Yes & No & Yes & Yes \\
\hline Time FE & Yes & Yes & Yes & Yes \\
\hline N. of Banks & 1249 & 1249 & 848 & 848 \\
\hline N. of Obs. & 19217 & 19217 & 12985 & 12985 \\
\hline Adj. R2 & 0.0242 & 0.0237 & 0.0339 & 0.0533 \\
\hline Difference-in-difference effect for & $\operatorname{anks}(\mathrm{BHC}=$ & and $\mathrm{BHC}$ & anks $(\mathrm{BHC}$ & \\
\hline "Event $\times$ Affected" for $\mathrm{BHC}=0$ & $\begin{array}{r}0.0106^{* *} \\
(0.0045)\end{array}$ & $\begin{array}{r}0.0154^{* * *} \\
(0.0052)\end{array}$ & $\begin{array}{r}0.0134^{* *} \\
(0.0054)\end{array}$ & $\begin{array}{r}0.0134^{* *} \\
(0.0052)\end{array}$ \\
\hline "Event $\times$ Affected" for $\mathrm{BHC}=1$ & $\begin{array}{r}0.0012 \\
(0.0019)\end{array}$ & $\begin{array}{r}0.0014 \\
(0.0020)\end{array}$ & $\begin{array}{r}0.0033 \\
(0.0021)\end{array}$ & $\begin{array}{r}0.0026 \\
(0.0021)\end{array}$ \\
\hline
\end{tabular}


Table 5: The role of bank capitalization

This table shows results for regressions of Equation (3) in which banks' total risk-based capital ratio is the dependent variable and the terms Event, Affected and Event $\times$ Affected are interacted with a variable RBCR that represents the average risk-based capital ratio for each bank for the eight quarters before the event demeaned by the sample average before the event. The sample includes all independent banks (not part of a bank holding company) in Alabama, Louisiana, Mississippi, Florida, Texas, Georgia, Tennessee, Arkansas and Oklahoma over the period of \pm 2 years around the 2005 hurricane season (Q3 2003 to Q4 2007).

At the bottom, we present estimates of the difference-in-difference effect of Event $\times$ Affected for the $25^{t h}$ and $75^{t h}$ percentile of the distribution of RBCR.

Event is a dummy variable that is zero for the pre-hurricane period and one after the hurricane season. Affected is a dummy variable that separates banks located in counties that were affected by the hurricanes (Affected=1) and banks located in counties that were unaffected $($ Affected $=0)$. Event $\times$ Affected is an interaction term for the variables Event and Affected. Credit demand is the log of the volume of loan applications as reported under the Home Mortgage Disclosure Act. RoA is banks' return over assets. NPL represents non-performing loans over assets. Bank size is the natural logarithm of banks' number of employees. Regional unemployment rate represents the quarterly unemployment rate for the county where a bank's headquarters is based. A detailed description of all variables is given in Table 1.

Bank fixed effects (Bank FE) and year dummies (Time FE) are included in the regressions as stated in the table below. We show clustered standard errors on bank level in parentheses. The adjusted R-squared is the within R-squared for regressions with bank fixed effects. The ${ }^{* *},{ }^{* *}$ and ${ }^{*}$ stand for significant coefficients at the $1 \%, 5 \%$, and $10 \%$ levels, respectively.

\begin{tabular}{|c|c|c|c|c|}
\hline & \multicolumn{4}{|c|}{ risk-based capital ratio } \\
\hline Event & $\begin{array}{r}-0.0135^{* * *} \\
(0.0031)\end{array}$ & $\begin{array}{r}-0.0073^{* * *} \\
(0.0026)\end{array}$ & $\begin{array}{r}-0.0074^{* * *} \\
(0.0024)\end{array}$ & $\begin{array}{l}-0.0045^{*} \\
(0.0024)\end{array}$ \\
\hline Event $\times$ Affected & $\begin{array}{r}0.0106^{* *} \\
(0.0043)\end{array}$ & $\begin{array}{r}0.0108^{* *} \\
(0.0043)\end{array}$ & $\begin{array}{r}0.0139^{* *} \\
(0.0057)\end{array}$ & $\begin{array}{r}0.0134^{* *} \\
(0.0053)\end{array}$ \\
\hline Event $\times$ RBCR & $\begin{array}{r}-0.2274^{* * *} \\
(0.0498)\end{array}$ & $\begin{array}{r}-0.2315^{* * *} \\
(0.0499)\end{array}$ & $\begin{array}{r}-0.1991 * * * \\
(0.0637)\end{array}$ & $\begin{array}{r}-0.2185^{* * *} \\
(0.0592)\end{array}$ \\
\hline Event $\times$ Affected $\times$ RBCR & $\begin{array}{r}0.1356 \\
(0.0940)\end{array}$ & $\begin{array}{r}0.1416 \\
(0.0962)\end{array}$ & $\begin{array}{r}0.0862 \\
(0.1455)\end{array}$ & $\begin{array}{r}0.0967 \\
(0.1405)\end{array}$ \\
\hline Affected & & $\begin{array}{r}0.0000 \\
(0.0000)\end{array}$ & & \\
\hline $\mathrm{RBCR}$ & & $\begin{array}{r}1.0000^{* * * *} \\
(0.0000)\end{array}$ & & \\
\hline Affected $\times$ RBCR & & $\begin{array}{r}0.0000 \\
(0.0000)\end{array}$ & & \\
\hline Credit demand & & & $\begin{array}{r}-0.0007 \\
(0.0030)\end{array}$ & $\begin{array}{r}-0.0004 \\
(0.0029)\end{array}$ \\
\hline RoA & & & & $\begin{array}{r}-0.0024 \\
(0.0026)\end{array}$ \\
\hline NPL & & & & $\begin{array}{r}-0.0485 \\
(0.2346)\end{array}$ \\
\hline $\log$ (No. of employees) & & & & $\begin{array}{r}-0.0312^{* * *} \\
(0.0085)\end{array}$ \\
\hline Regional unemployment rate & & & & $\begin{array}{r}0.0840 \\
(0.1277)\end{array}$ \\
\hline Constant & $\begin{array}{r}0.1774^{* * *} \\
(0.0016)\end{array}$ & $\begin{array}{r}0.1715^{* * *} \\
(0.0010)\end{array}$ & $\begin{array}{r}0.1690^{* * *} \\
(0.0219)\end{array}$ & $\begin{array}{r}0.2875^{* * *} \\
(0.0466)\end{array}$ \\
\hline Bank FE & Yes & No & Yes & Yes \\
\hline Time FE & Yes & Yes & Yes & Yes \\
\hline N. of Banks & 257 & 257 & 178 & 178 \\
\hline N. of Obs. & 3779 & 3779 & 2589 & 2589 \\
\hline Adj. R2 & 0.1025 & 0.8301 & 0.0782 & 0.1222 \\
\hline Difference-in-difference effect for different $p$ & ntiles of $\mathrm{RB}$ & & & \\
\hline "Event $\times$ Affected" for the $25^{\text {th }}$ percentile & $\begin{array}{r}0.0042 \\
(0.0052)\end{array}$ & $\begin{array}{r}0.0040 \\
(0.0054)\end{array}$ & $\begin{array}{r}0.0098 \\
(0.0062)\end{array}$ & $\begin{array}{r}0.0088 \\
(0.0059)\end{array}$ \\
\hline "Event $\times$ Affected" for the $75^{\text {th }}$ percentile & $\begin{array}{r}0.0143^{* *} \\
(0.0055)\end{array}$ & $\begin{array}{r}0.0146^{* * *} \\
(0.0056)\end{array}$ & $\begin{array}{r}0.0162^{* *} \\
(0.0084)\end{array}$ & $\begin{array}{r}0.0161^{* *} \\
(0.0081)\end{array}$ \\
\hline
\end{tabular}




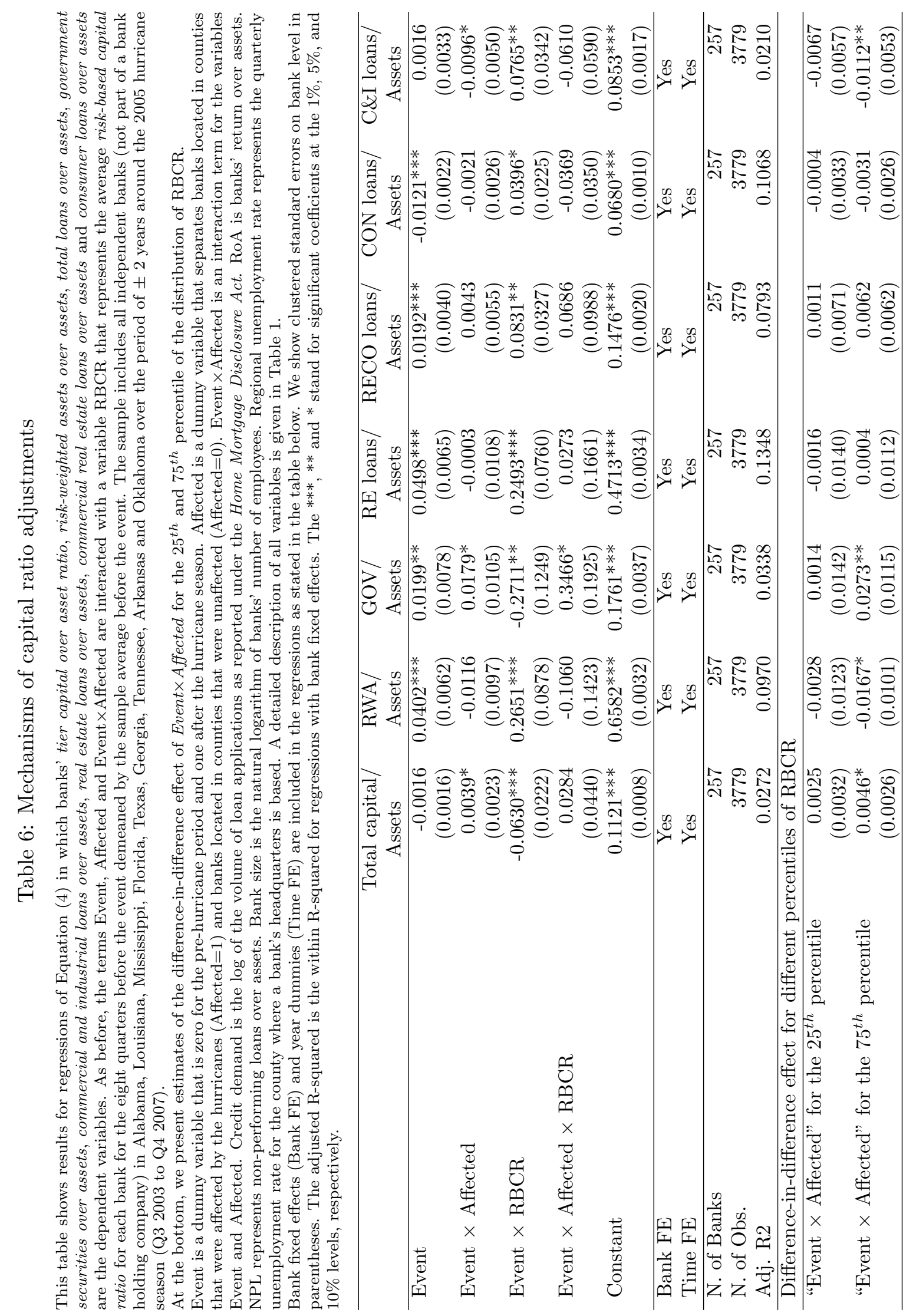


Table 7: Robustness - alternative regional samples

This table shows results for regressions of Equation (1) in which banks' total risk-based capital ratio is the dependent variable.

Regressions presented in this table are for different samples: AL \& FL shows results for banks in Florida and Alabama only; AL\&LA\&FL\&MS comprise counties in Alabama, Louisiana, Florida and Mississippi; Baseline includes counties in Alabama, Louisiana, Florida, Mississippi, Texas, Georgia, Tennessee, Arkansas and Oklahoma; Southeast U.S. comprises all previous counties plus North Carolina and South Carolina. The sample includes all independent banks (not part of a bank holding company) over the period of \pm 2 years around the 2005 hurricane season (Q3 2003 to Q4 2007).

Event is a dummy variable that is zero for the pre-hurricane period and one after the hurricane season. Affected is a dummy variable that separates banks located in counties that were affected by the hurricanes (Affected=1) and banks located in counties that were unaffected (Affected=0). Event $\times$ Affected is an interaction term for the variables Event and Affected.

Bank fixed effects (Bank FE) and year dummies (Time FE) are included in each regression. We show clustered standard errors on bank level in parentheses. The adjusted $\mathrm{R}$-squared is the within $\mathrm{R}$-squared. The ${ }^{* * *}$, ** and ${ }^{*}$ stand for significant coefficients at the $1 \%, 5 \%$, and $10 \%$ levels, respectively.

\begin{tabular}{lrrrr}
\hline & \multicolumn{4}{c}{ risk-based capital ratio } \\
& AL\&FL & AL\&LA\&FL\&MS & Baseline & Southeast U.S. \\
\hline Event & $-0.0120^{* * *}$ & $-0.0130^{* * *}$ & $-0.0138^{* * *}$ & $-0.0055^{* * *}$ \\
& $(0.0045)$ & $(0.0046)$ & $(0.0034)$ & $(0.0019)$ \\
Event $\times$ Affected & $0.0228^{* * *}$ & $0.0149^{* *}$ & $0.0106^{* *}$ & $0.0107^{* *}$ \\
& $(0.0073)$ & $(0.0060)$ & $(0.0045)$ & $(0.0043)$ \\
Constant & $0.1552^{* * *}$ & $0.1663^{* * *}$ & $0.1774^{* * *}$ & $0.1707^{* * *}$ \\
& $(0.0021)$ & $(0.0017)$ & $(0.0016)$ & $(0.0010)$ \\
\hline Bank FE & Yes & Yes & Yes & Yes \\
Time FE & Yes & Yes & Yes & Yes \\
\hline N. of Banks & 83 & 115 & 257 & 273 \\
N. of Obs. & 1204 & 1666 & 3779 & 4002 \\
Adj. R2 & 0.0861 & 0.0647 & 0.0325 & 0.0370 \\
\hline
\end{tabular}


Table 8: Robustness - cross section results

This table shows results for cross-section regressions of Equation (1) in which banks' total risk-based capital ratio is the dependent variable. The sample includes all independent banks (not part of a bank holding company) in Alabama, Louisiana, Mississippi, Florida, Texas, Georgia, Tennessee, Arkansas and Oklahoma over the period of \pm 2 years around the 2005 hurricane season (Q3 2003 to Q4 2007). The regressions comprise for each bank collapsed mean values for the two years before and the two years after the event.

Event is a dummy variable that is zero for the pre-hurricane period and one after the hurricane season. Affected is a dummy variable that separates banks located in counties that were affected by the hurricanes (Affected=1) and banks located in counties that were unaffected (Affected=0). Event $\times$ Affected is an interaction term for the variables Event and Affected. Credit demand is the log of the volume of loan applications as reported under the Home Mortgage Disclosure Act. RoA is banks' return over assets. NPL represents non-performing loans over assets. Bank size is the natural logarithm of banks' number of employees. Regional unemployment rate represents the quarterly unemployment rate for the county where a bank's headquarters is based. A detailed description of all variables is given in Table 1.

We show clustered standard errors on bank level in parentheses. The ${ }^{* * *}, * *$ and $*$ stand for significant coefficients at the $1 \%, 5 \%$, and $10 \%$ levels, respectively.

\begin{tabular}{lrrr}
\hline & \multicolumn{3}{c}{ risk-based capital ratio } \\
\hline Event & $-0.0090^{* * *}$ & $-0.0084^{* * *}$ & -0.0038 \\
Event $\times$ Affected & $(0.0026)$ & $(0.0029)$ & $(0.0040)$ \\
& $0.0115^{* * *}$ & $0.0121^{* *}$ & $0.0148^{* * *}$ \\
Affected & $(0.0044)$ & $(0.0052)$ & $(0.0056)$ \\
& -0.0027 & 0.0038 & -0.0001 \\
Credit demand & $(0.0075)$ & $(0.0082)$ & $(0.0086)$ \\
& & $-0.0123^{* * *}$ & $-0.0101^{* *}$ \\
RoA & & $(0.0043)$ & $(0.0045)$ \\
& & -0.0062 \\
NPL & & $(0.0042)$ \\
& & 0.1463 \\
Bank size & & $(0.4321)$ \\
Regional unemployment rate & & -0.0050 \\
& & $(0.0043)$ \\
Constant & & 0.5553 \\
& & $(0.4218)$ \\
N. of Banks & & $0.2350^{* * *}$ \\
N. of Obs. & & $(0.0389)$ \\
Adj. R2 & & & 178 \\
\hline
\end{tabular}


Table 9: Robustness - placebo event

This table shows results for regressions of Equation (1) in which banks' total risk-based capital ratio is the dependent variable, and the placebo event is placed three years before the hurricane season of 2005. The sample includes all independent banks (not part of a bank holding company) in Alabama, Louisiana, Mississippi, Florida, Texas, Georgia, Tennessee, Arkansas and Oklahoma over the period of \pm 2 years around the 2005 hurricane season (Q3 2003 to Q4 2007).

Event is a dummy variable that is zero for the pre-hurricane period and one after the hurricane season. Affected is a dummy variable that separates banks located in counties that were affected by the hurricanes (Affected=1) and banks located in counties that were unaffected (Affected=0). Event $\times$ Affected is an interaction term for the variables Event and Affected. Credit demand is the log of the volume of loan applications as reported under the Home Mortgage Disclosure Act. RoA is banks' return over assets. NPL represents non-performing loans over assets. Bank size is the natural logarithm of banks' number of employees. Regional unemployment rate represents the quarterly unemployment rate for the county where a bank's headquarters is based. A detailed description of all variables is given in Table 1.

Bank fixed effects (Bank FE) and year dummies (Time FE) are included in the regressions as stated in the table below. We show clustered standard errors on bank level in parentheses. The adjusted R-squared is the within R-squared for regressions with bank fixed effects. The ${ }^{* * *}, *^{*}$ and $*$ stand for significant coefficients at the $1 \%, 5 \%$, and $10 \%$ levels, respectively.

\begin{tabular}{|c|c|c|c|c|}
\hline \multirow{2}{*}{ Event } & \multicolumn{4}{|c|}{ risk-based capital ratio } \\
\hline & $\begin{array}{r}-0.0090^{* *} \\
(0.0036)\end{array}$ & $\begin{array}{r}-0.0076^{* *} \\
(0.0038)\end{array}$ & $\begin{array}{r}-0.0125^{* * *} \\
(0.0046)\end{array}$ & $\begin{array}{r}-0.0054 \\
(0.0046)\end{array}$ \\
\hline Event $\times$ Affected & $\begin{array}{r}-0.0001 \\
(0.0053)\end{array}$ & $\begin{array}{r}0.0009 \\
(0.0057)\end{array}$ & $\begin{array}{r}0.0024 \\
(0.0062)\end{array}$ & $\begin{array}{r}0.0018 \\
(0.0058)\end{array}$ \\
\hline Affected & & $\begin{array}{r}-0.0050 \\
(0.0087)\end{array}$ & & \\
\hline Credit demand & & & $\begin{array}{r}-0.0004 \\
(0.0025)\end{array}$ & $\begin{array}{r}-0.0011 \\
(0.0023)\end{array}$ \\
\hline RoA & & & & $\begin{array}{r}-0.0097^{* * *} \\
(0.0030)\end{array}$ \\
\hline NPL & & & & $\begin{array}{r}0.0218 \\
(0.3522)\end{array}$ \\
\hline Bank size & & & & $\begin{array}{r}-0.0292^{* *} \\
(0.0119)\end{array}$ \\
\hline Regional unemployment rate & & & & $\begin{array}{r}-0.0410 \\
(0.0998)\end{array}$ \\
\hline Constant & $\begin{array}{r}0.1804^{* * *} \\
(0.0015) \\
\end{array}$ & $\begin{array}{r}0.1814^{* * *} \\
(0.0053) \\
\end{array}$ & $\begin{array}{r}0.1768^{* * *} \\
(0.0189) \\
\end{array}$ & $\begin{array}{r}0.3019^{* * *} \\
(0.0476)\end{array}$ \\
\hline Bank FE & Yes & No & Yes & Yes \\
\hline Time FE & Yes & Yes & Yes & Yes \\
\hline N. of Banks & 257 & 257 & 178 & 178 \\
\hline N. of Obs. & 3689 & 3689 & 2575 & 2575 \\
\hline Adj. R2 & 0.0395 & 0.0058 & 0.0418 & 0.1370 \\
\hline
\end{tabular}




\section{Appendix: Short-term effects on bank asset quality}

In this section, we provide further empirical evidence that Hurricane Katrina, Rita and Wilma had an adverse effect on banks' asset quality by exploring bank profitability and bank risk in Q3 and Q4 2005. In particular, we expect lower bank profitability and higher bank risk.

Estimation. Formally, we estimate the following equation:

$$
\mathrm{Y}_{i t}=\nu_{i}+\beta_{1} \text { EventST }_{t}+\beta_{2}\left(\text { EventST }_{t} \times \operatorname{Affected}_{i}\right)+\tau_{\gamma}+\epsilon_{i t}
$$

The dependent variable $Y_{i t}$ stands for return on assets (RoA) or $z$-score of bank $i$ at quarter $t$, which reflects bank profitability and bank stability, respectively. ${ }^{17}$ The variable $\nu_{i}$ represents bank fixed effects. The variable Event $S T_{t}$ is a short-term time dummy with a value of zero for the two quarters before the hurricanes (Q1 and Q2 2005) and a value of one for the two quarters when the hurricanes occured (Q3 and Q4 2005). The variable Affected ${ }_{i}$ is a dummy variable of bank $i$ that is one if the bank is located in a county classified by FEMA as eligible for "public and private disaster assistance" and thus belongs to the treatment group, and zero otherwise (for the control group). Hence, the interaction term EventST $T_{t} \times$ Affected $_{i}$ is one if

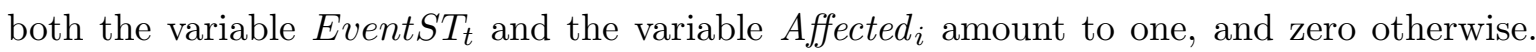
The corresponding coefficient $\beta_{2}$ is the main interest. It captures the average effect of the hurricanes on the RoA or $z$-score of affected banks relative to the control group. Note that the single term Affected $_{i}$ is not directly included in the equation because it is fully captured by the bank fixed effects. The variable $\tau_{\gamma}$ represents yearly time fixed effects. Finally, $\epsilon_{i t}$ is the idiosyncratic error term. To account for heterogeneity among banks, we use clustered standard errors at the bank level.

Results. First, as shown in Column 1 of Table 10, we estimate the effect of Hurricanes Katrina, Rita and Wilma on banks' RoA. We observe that profits decline significantly for banks that were affected by the hurricanes relative to banks that were not affected. The

\footnotetext{
${ }^{17}$ The z-score is defined as the natural logarithm of the sum of a bank's RoA and its core capital over assets, standardized by the standard deviation of the bank's RoA. A lower z-score indicates lower bank stability.
} 
effect of 0.0009 represents about $10 \%$ of banks' average RoA of 0.01 . The true effect on banks may be even larger because banks tend to underreport losses in times of crisis (Gunther and Moore, 2003). Regression results for banks' z-scores are presented in Column 2. The results show that affected banks became significantly more risky during the two quarters when the hurricanes met the U.S. Gulf Coast relative to unaffected banks. The coefficient of -0.1187 means that the ratio $(R o A+$ Capital) $/ S D(R o A)$, where $R o A$ is return on assets, Capital is core capital over assets and $S D(R o A)$ is the standard deviation of $R o A$, decreases by about 11.87 percent for affected banks relative to unaffected banks following the 2005 hurricane season, which is economically highly relevant. Summing up, the regression results provide evidence that the 2005 hurricane season had an adverse effect on bank's asset quality, as reflected in lower bank profitability and higher bank risk.

Table 10: Evidence on short-term effects

This table shows results for regressions of Equation (5) in which banks' return on assets (RoA) and banks' z-scores are the dependent variables. The sample includes all independent banks (not part of a bank holding company) in Alabama, Louisiana, Mississippi, Florida, Texas, Georgia, Tennessee, Arkansas and Oklahoma over the four quarters of 2005.

Event is a dummy variable that is zero for the first two quarters of 2005 and one for the last two quarters of 2005

Affected is a dummy variable that separates banks located in counties that were affected by the hurricanes (Affected=1) and banks located in counties that were unaffected (Affected=0). Event $\times$ Affected is an interaction term for the variables Event and Affected.

Bank fixed effects (Bank FE) and quarterly dummies (Time FE) are included in each regression. We show clustered standard errors on bank level in parentheses. The adjusted R-squared provides the within R-squared. The ***, ** and * stand for significant coefficients at the $1 \%, 5 \%$, and $10 \%$ levels, respectively.

\begin{tabular}{|c|c|c|}
\hline & RoA & Z-score \\
\hline \multirow[t]{2}{*}{ EventST } & -0.0002 & $0.1301^{* * *}$ \\
\hline & $(0.0004)$ & $(0.0290)$ \\
\hline \multirow[t]{2}{*}{ EventST $\times$ Affected } & $-0.0009^{* *}$ & $-0.1187^{* * *}$ \\
\hline & $(0.0004)$ & $(0.0414)$ \\
\hline \multirow[t]{2}{*}{ Constant } & $0.0105^{* * *}$ & $3.7708^{* * *}$ \\
\hline & $(0.0002)$ & $(0.0145)$ \\
\hline Bank FE & Yes & Yes \\
\hline Time FE & Yes & Yes \\
\hline N. of Banks & 257 & 257 \\
\hline N. of Obs. & 1019 & 1013 \\
\hline Adj. R2 & 0.0178 & 0.0489 \\
\hline
\end{tabular}




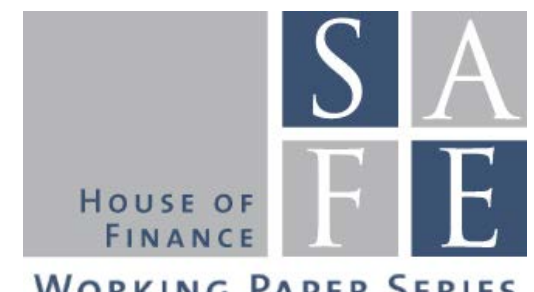

WORKING PAPER SERIES

\section{Recent Issues}

No. 93 Shafik Hebous, Tom Zimmermann

No. 92 Christoph Hambel, Holger Kraft, Eduardo S. Schwartz

No.91 Anne-Caroline Hüser

No. $90 \quad$ Pinar Topal

No. 89 Julia Braun, Alfons J. Weichenrieder

No. 88 Ester Faia, Beatrice Weder di Mauro

No. 87 Iñaki Aldasoro, Domenico Delli Gatti, Ester Faia

No. 86 Agar Brugiavini, Danilo Cavapozzi, Mario Padula, Yuri Pettinicchi

No. 85 Holger Kraft, Claus Munk, Sebastian Wagner

No. 84 Raimond Maurer, Olivia S. Mitchell, Ralph Rogalla, Tatjana Schimetschek

No. 83 Patrick Grüning

No. 82 Edgar Vogel, Alexander Ludwig, Axel Börsch-Supan

No. 81 Jens-Hinrich Binder

No. 80 Enrique G. Mendoza, Linda L. Tesar, Jing Zhang

No. 79 Òscar Jordà, Alan M. Taylor
Revisiting the Narrative Approach of Estimating Tax Multipliers

Optimal Carbon Abatement in a Stochastic Equilibrium Model with Climate Change

Too Interconnected to Fail: A Survey of the Interbank Networks Literature

Fiscal Stimulus and Labor Market Flexibility

Does Exchange of Information between Tax Authorities Influence Multinationals' Use of Tax Havens?

Cross-Border Resolution of Global Banks

Bank Networks: Contagion, Systemic Risk and Prudential Policy

Financial education, literacy and investment attitudes

Housing Habits and Their Implications for LifeCycle Consumption and Investment

Will They Take the Money and Work? An Empirical Analysis of People's Willingness to Delay Claiming Social Security Benefits for a Lump Sum

International Endogenous Growth, Macro Anomalies, and Asset Prices

Aging and Pension Reform: Extending the Retirement Age and Human Capital Formation

Resolution Planning and Structural Bank Reform within the Banking Union

Saving Europe?: The Unpleasant Arithmetic of Fiscal Austerity in Integrated Economies

The Time for Austerity: Estimating the Average Treatment Effect of Fiscal Policy 